ARTICLE

\title{
Gold-like activity copper-like selectivity of heteroatomic transition metal carbides for electrocatalytic carbon dioxide reduction reaction
}

\author{
Mohammadreza Esmaeilirad (10) 1,6, Artem Baskin (10) 2,6, Alireza Kondori (1) 1, Ana Sanz-Matias (1) 2, Jin Qian², \\ Boao Song (10 ${ }^{3}$, Mahmoud Tamadoni Saray ${ }^{3}$, Kamil Kucuk (D) ${ }^{4}$, Andres Ruiz Belmonte ${ }^{1}$, \\ Pablo Navarro Munoz Delgado ${ }^{1}$, Junwon Park ${ }^{1}$, Rahman Azari ${ }^{5}$, Carlo U. Segre (1) ${ }^{4}$, Reza Shahbazian-Yassar (10 ${ }^{3}$, \\ David Prendergast (1D ${ }^{2 \times} \&$ Mohammad Asadi (iD ${ }^{1 \times}$
}

An overarching challenge of the electrochemical carbon dioxide reduction reaction $\left(e \mathrm{CO}_{2} \mathrm{RR}\right)$ is finding an earth-abundant, highly active catalyst that selectively produces hydrocarbons at relatively low overpotentials. Here, we report the $\mathrm{eCO}_{2} \mathrm{RR}$ performance of two-dimensional transition metal carbide class of materials. Our results indicate a maximum methane $\left(\mathrm{CH}_{4}\right)$ current density of $-421.63 \mathrm{~mA} / \mathrm{cm}^{2}$ and a $\mathrm{CH}_{4}$ faradic efficiency of $82.7 \% \pm 2 \%$ for ditungsten carbide $\left(\mathrm{W}_{2} \mathrm{C}\right)$ nanoflakes in a hybrid electrolyte of $3 \mathrm{M}$ potassium hydroxide and $2 \mathrm{M}$ choline-chloride. Powered by a triple junction photovoltaic cell, we demonstrate a flow electrolyzer that uses humidified $\mathrm{CO}_{2}$ to produce $\mathrm{CH}_{4}$ in a 700-h process under one sun illumination with a $\mathrm{CO}_{2} \mathrm{RR}$ energy efficiency of about $62.3 \%$ and a solar-to-fuel efficiency of $20.7 \%$. Density functional theory calculations reveal that dissociation of water, chemisorption of $\mathrm{CO}_{2}$ and cleavage of the $\mathrm{C}-\mathrm{O}$ bond-the most energy consuming elementary steps in other catalysts such as copper-become nearly spontaneous at the $\mathrm{W}_{2} \mathrm{C}$ surface. This results in instantaneous formation of adsorbed $\mathrm{CO}$-an important reaction intermediate-and an unlimited source of protons near the tungsten surface sites that are the main reasons for the observed superior activity, selectivity, and small potential.

\footnotetext{
${ }^{1}$ Department of Chemical and Biological Engineering, Illinois Institute of Technology, Chicago, IL, USA. ${ }^{2}$ Molecular Foundry, Lawrence Berkeley National Laboratory, Berkeley, CA, USA. ${ }^{3}$ Department of Mechanical and Industrial Engineering, University of Illinois at Chicago, Chicago, IL, USA. ${ }^{4}$ Department of Physics \& CSRRI, Illinois Institute of Technology, Chicago, IL, USA. ${ }^{5}$ Department of Architecture, Pennsylvania State University, University Park, PA, USA

${ }^{6}$ These authors contributed equally: Mohammadreza Esmaeilirad, Artem Baskin. ${ }^{凶}$ email: dgprendergast@lbl.gov; m.asadi@iit.edu
} 
$\mathrm{T}$ he electrocatalytic carbon dioxide reduction reaction $\left(e \mathrm{CO}_{2} \mathrm{RR}\right)$ driven by renewable energy has great potential for the sustainable production of chemicals and fuels at the gigaton scale that can be used any time, any place ${ }^{1-4}$. It also offers a promising way to store energy in chemical bonds due to having nearly two orders of magnitude higher energy density compared to the most advanced battery technologies ${ }^{5}$. However, reducing $\mathrm{CO}_{2}$ to value-added chemicals is both costly and slow based on intrinsic thermodynamics and kinetics, making the goal of an effective and feasible process a real challenge ${ }^{6-9}$.

Conventional pure metal catalysts such as gold $(\mathrm{Au})$, palladium (Pd), silver (Ag), and newly developed transition metal dichalcogenides (TMDCs) ${ }^{8,10-18}$ are known to exhibit high activities for the $\mathrm{CO}_{2} \mathrm{RR}$ in different electrolyte solutions ${ }^{19-26}$. However, these catalysts are mainly selective for carbon monoxide (CO), known as an intermediate product ${ }^{8,27}$. Other catalysts such as copper $(\mathrm{Cu})$ and $\mathrm{Cu}$-based catalysts have the ability to reduce $\mathrm{CO}_{2}$ to various chemicals such as methane $\left(\mathrm{CH}_{4}\right)$, ethylene $\left(\mathrm{C}_{2} \mathrm{H}_{4}\right)$, formic acid $(\mathrm{HCOOH})$, methanol $\left(\mathrm{CH}_{3} \mathrm{OH}\right)$, and ethanol $\left(\mathrm{C}_{2} \mathrm{H}_{5} \mathrm{OH}\right)^{28-36}$. Despite their good selectivity, these catalysts require high potentials-excess energy-to achieve suitable current densities-reaction rates-impeding their use for effective production of chemicals and fuels ${ }^{37,38}$. Therefore, an effective catalyst needs to be developed to selectively produce hydrocarbons at high rates at relatively low potentials.

Heteroatomic transition metal carbide (TMC) catalysts, also known as MXenes, have recently received great attention for various electrocatalytic reactions due to their unique structural and electronic properties ${ }^{39-42}$. In particular, $\mathrm{M}_{2} \mathrm{C}$ ( $\mathrm{M}$ denotes transition metals) stoichiometry of this class of two-dimensional materials forms layered structures of M-C-M where a plane of carbon atoms is sandwiched between two hexagonal planes of metal atoms. This structure provides a high density of active metal atoms at the surface breaking conventional scaling relationships that limit the electrocatalytic performance of their counterparts such as TMDCs and pure metals ${ }^{43}$. However, there is limited knowledge of their performance and characteristics as $\mathrm{eCO}_{2} \mathrm{RR}$ catalysts under actual experimental conditions.

In this work, we investigate the performance of di-tungsten carbide $\left(\mathrm{W}_{2} \mathrm{C}\right)$, di-molybdenum carbide $\left(\mathrm{Mo}_{2} \mathrm{C}\right)$, diniobium carbide $\left(\mathrm{Nb}_{2} \mathrm{C}\right)$, and divanadium carbide $\left(\mathrm{V}_{2} \mathrm{C}\right)$ nanoflakes $(\mathrm{NFs})$ as inexpensive, non-precious members of TMCs for $\mathrm{eCO}_{2} \mathrm{RR}$. Our electrochemical results indicate that $\mathrm{W}_{2} \mathrm{C} N F$ sork remarkably well for $\mathrm{eCO}_{2} \mathrm{RR}$ by achieving a maximum $\mathrm{CH}_{4}$ formation current density of $-421.63 \mathrm{~mA} / \mathrm{cm}^{2}$ and faradaic efficiency of $82.7 \% \pm 2$ that are the highest values yet reported. These results suggest a catalytic activity higher than $\mathrm{Au}$, product selectivity similar to $\mathrm{Cu}$ in the $\mathrm{CO}_{2} \mathrm{RR}$ for $\mathrm{W}_{2} \mathrm{C}$ NFs. Our DFT calculations also reveal that dissociation of water, chemisorption of $\mathrm{CO}_{2}$, and cleavage of the $\mathrm{C}-\mathrm{O}$ bond, known as the most energy-consuming elementary steps in other catalysts, become nearly spontaneous at the $\mathrm{W}_{2} \mathrm{C}$ surface and are the main reason for the observed superior activity, selectivity, and small overpotential for $\mathrm{CH}_{4}$ production.

\section{Results and discussion}

The TMC NFs i.e., $\mathrm{W}_{2} \mathrm{C}, \mathrm{Mo}_{2} \mathrm{C}, \mathrm{Nb}_{2} \mathrm{C}$, and $\mathrm{V}_{2} \mathrm{C}$ were synthesized using a carburization process followed by the liquid exfoliation technique (Supplementary section 1$)^{27,44,45}$. The electrocatalytic performance of TMC NFs with similar crystallite sizes $(25.4 \pm 5 \mathrm{~nm})$ were then studied in a three-electrode cell and compared with $\mathrm{Au}$ and $\mathrm{Cu}$ nanoparticles (NPs), conventional catalysts for this reaction, ${ }^{46}$ under identical experimental conditions (Supplementary section 2). To improve the $\mathrm{CO}_{2} \mathrm{RR}$ performance in competing with hydrogen evolution reaction (HER), we have employed a mixture of $3 \mathrm{M}$ potassium hydroxide $(\mathrm{KOH})$ and $2 \mathrm{M}$ choline chloride (CC) solution ( $\mathrm{KOH}: \mathrm{CC} 3 \mathrm{M}: 2 \mathrm{M}$ ) as the electrolyte in this study ${ }^{47}$.

The linear sweep voltammetry (LSV) experiments and a realtime product stream analysis show that $\mathrm{CO}_{2} \mathrm{RR}$ on the $\mathrm{W}_{2} \mathrm{C}$ surface starts at a potential of $-122.7 \mathrm{mV}$ vs reversible hydrogen electrode (RHE) by producing $\mathrm{CO}$ and $\mathrm{H}_{2}$ and reach maximum $\mathrm{CO}_{2} \mathrm{RR}$ current density $\left(j_{\mathrm{CO} 2 \mathrm{RR}}\right)$ of $-548.9 \mathrm{~mA} / \mathrm{cm}^{2}$ at $-1.05 \mathrm{~V}$ vs RHE (Supplementary Figs. 2-4 and Fig. 1a). As shown in Fig. 1a, $j_{\mathrm{CO} 2 \mathrm{RR}}$ of $-419.9,-381.9$, and $-350.8 \mathrm{~mA} / \mathrm{cm}^{2}$ were observed for $\mathrm{Mo}_{2} \mathrm{C}, \mathrm{Nb}_{2} \mathrm{C}$, and $\mathrm{V}_{2} \mathrm{C} \mathrm{NFs}$, respectively, at this potential (Supplementary section 3). However, $\mathrm{Au}$ and $\mathrm{Cu}$ NPs exhibit a $j_{\mathrm{CO} 2 \mathrm{RR}}$ of -208.11 and $-89.53 \mathrm{~mA} / \mathrm{cm}^{2}$ at $-1.05 \mathrm{~V}$ vs RHE (Fig. 1a). The selectivity analysis also indicates that TMC NFs produce hydrocarbons (i.e., $\mathrm{CH}_{4}, \mathrm{C}_{2} \mathrm{H}_{4}, \mathrm{CH}_{3} \mathrm{OH}$, and $\mathrm{C}_{2} \mathrm{H}_{5} \mathrm{OH}$ ) at a potential range of -0.45 to $-1.05 \mathrm{~V}$ vs $\mathrm{RHE}$ for $\mathrm{W}_{2} \mathrm{C}, \mathrm{Mo}_{2} \mathrm{C}$, and $\mathrm{Nb}_{2} \mathrm{C} N F$ and a potential range of -0.55 to $-1.05 \mathrm{~V}$ vs RHE for $\mathrm{V}_{2} \mathrm{C}$ NFs where $\mathrm{CH}_{4}$ is identified as the main product (Supplementary section 3 ).

Figure $1 \mathrm{~b}$ illustrates $\mathrm{CH}_{4}$ formation current densities $\left(j_{\mathrm{CH}}, \mathrm{mA} / \mathrm{cm}^{2}\right)$ of the TMC NFs compared to Cu NPs, a conventional catalyst for hydrocarbon production. The partial current densities of different products (i.e., $\mathrm{H}_{2}, \mathrm{CO}, \mathrm{CH}_{4}, \mathrm{C}_{2} \mathrm{H}_{4}$, $\mathrm{CH}_{3} \mathrm{OH}$, and $\mathrm{C}_{2} \mathrm{H}_{5} \mathrm{OH}$ ) were calculated by multiplying FEs and total current densities at different potentials (Supplementary section 3 and Supplementary Fig. 3). As shown in Fig. 1b, a maximum $j_{\mathrm{CH} 4}$ of $-421.63 \mathrm{~mA} / \mathrm{cm}^{2}$ is obtained for $\mathrm{W}_{2} \mathrm{C} \mathrm{NFs}$ at a potential of $-1.05 \mathrm{~V}$ vs RHE where $\mathrm{Nb}_{2} \mathrm{C} \mathrm{NFs}, \mathrm{Mo}_{2} \mathrm{C} \mathrm{NFs}$, and $\mathrm{V}_{2} \mathrm{C}$ NFs show values of $-219.16,-211.33$, and $-147.56 \mathrm{~mA} /$ $\mathrm{cm}^{2}$, respectively, at this potential. We also compared the $\mathrm{CH}_{4}$
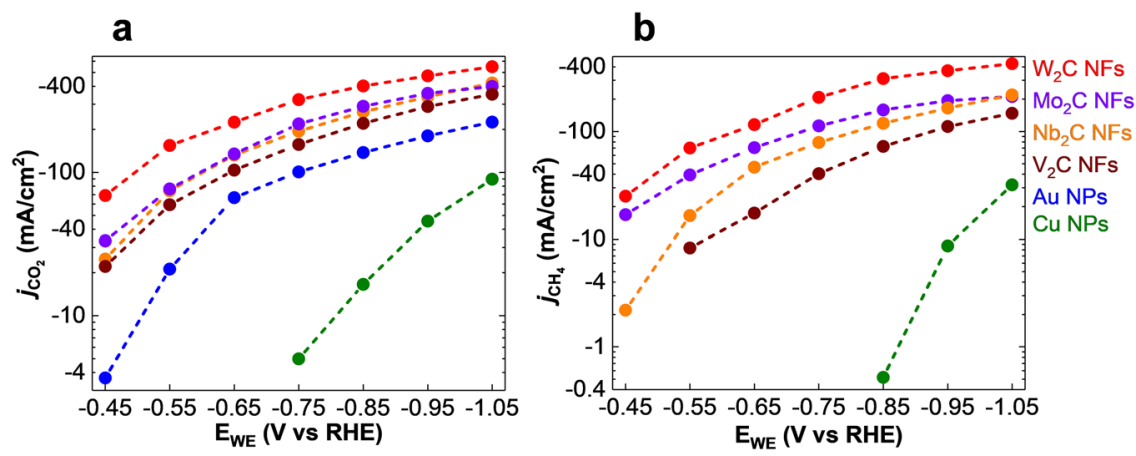

Fig. 1 Electrocatalytic performance of TMCs i.e., $\mathrm{W}_{2} \mathrm{C}, \mathrm{Mo}_{2} \mathrm{C}, \mathrm{Nb}_{2} \mathrm{C}, \mathrm{V}_{2} \mathrm{C}$ NFs in the two-compartment three-electrode electrochemical cell using $\mathrm{CO}_{2}$ saturated $\mathbf{K O H}: \mathbf{C C}\left(\mathbf{3} \mathbf{M : 2} \mathbf{M}\right.$ ) electrolyte. a $\mathrm{CO}_{2}$ reduction reaction current densities $\left(j_{\mathrm{CO} 2}\right)$ of TMCs compared to Au and $\mathrm{Cu}$ NPs at different cathodic potentials $\left(E_{W E}\right)$ under identical experimental condition. $\mathbf{b} \mathrm{CH}_{4}$ formation current densities $\left(j_{\mathrm{CH} 4}\right)$ of TMCs compared to $\mathrm{Cu} N P s$ at different potentials (EWE) under identical experimental condition. 
formation activity of TMCs i.e., $\mathrm{W}_{2} \mathrm{C}, \mathrm{Nb}_{2} \mathrm{C}, \mathrm{Mo}_{2} \mathrm{C}$, and $\mathrm{V}_{2} \mathrm{C} \mathrm{NFs}$ with state-of-the-art catalysts in the literature by calculating their maximum $\mathrm{CH}_{4}$ formation current densities $\left(j_{\text {max.CH}}\right.$, Supplementary Table 2$)^{46,48-54}$. Supplementary Table $2 \mathrm{~b}$ indicates that the $j_{\text {max.CH}}$ of $\mathrm{W}_{2} \mathrm{C}$ NFs is 3.6 and 4.2 times higher than recently studied $\mathrm{La}_{2} \mathrm{CuO}_{4}\left(-117 \mathrm{~mA} / \mathrm{cm}^{2} \text { at }-1.4 \mathrm{~V} \text { vs RHE }\right)^{51}$ and $\mathrm{Cu}-\mathrm{N}$ $\left(-100 \mathrm{~mA} / \mathrm{cm}^{2} \text { at }-1.0 \mathrm{~V} \text { vs } \mathrm{RHE}\right)^{48}$, respectively. The partial current densities of other hydrocarbon products i.e., $\mathrm{C}_{2} \mathrm{H}_{4}$, $\mathrm{CH}_{3} \mathrm{OH}$, and $\mathrm{C}_{2} \mathrm{H}_{5} \mathrm{OH}$ are also shown in Supplementary Fig. 3 (Supplementary section 3 ).

To evaluate the intrinsic activity of $\mathrm{W}_{2} \mathrm{C}$ NFs, we measured $\mathrm{CH}_{4}$ formation turnover frequency $\left(\mathrm{TOF}_{\mathrm{CH} 4}\right)$ by normalizing its activity to the number of active atoms at the surface using the roughness factor method and compared it with the other catalysts in this study (Supplementary section 5). Our calculations indicate a $\mathrm{TOF}_{\mathrm{CH} 4}$ of $10.42 \mathrm{~s}^{-1}$ at a potential of $-1.05 \mathrm{~V}$ vs RHE for $\mathrm{W}_{2} \mathrm{C}$ NFs; by comparison, $\mathrm{TOF}_{\mathrm{CH} 4}$ of $4.54,3.74$, and $2.79 \mathrm{~s}^{-1}$ were calculated for $\mathrm{Mo}_{2} \mathrm{C} \mathrm{NFs}, \mathrm{Nb}_{2} \mathrm{C}$ NFs, and $\mathrm{V}_{2} \mathrm{C}$ NFs, respectively. The calculated $\mathrm{TOF}_{\mathrm{CH} 4}$ of $\mathrm{W}_{2} \mathrm{C}$ NFs at the potential of $-1.05 \mathrm{~V}$ vs RHE is about two orders of magnitude higher than that of $\mathrm{Cu}$ NPs $\left(0.0736 \mathrm{~s}^{-1}\right)$ under identical experimental conditions (Supplementary Fig. 7a). Moreover, total $\mathrm{CO}_{2} \mathrm{RR}$ turnover frequencies $\left(\mathrm{TOF}_{\mathrm{CO} 2 \mathrm{RR}}\right)$ of $19.09,19.36,17.82$, and $17.55 \mathrm{~s}^{-1}$ were calculated for $\mathrm{W}_{2} \mathrm{C} \mathrm{NFs}, \mathrm{Mo}_{2} \mathrm{C} \mathrm{NFs}, \mathrm{Nb}_{2} \mathrm{C}$ NFs, and $\mathrm{V}_{2} \mathrm{C}$ NFs, respectively, where $\mathrm{Au}$ NPs and $\mathrm{Cu}$ NPs exhibit $\mathrm{TOF}_{\mathrm{CO} 2 \mathrm{RR}}$ of 4.35 and $0.1956 \mathrm{~s}^{-1}$, respectively (Supplementary Fig. $7 \mathrm{f}$ ). These results suggest the superior $\mathrm{CH}_{4}$ selectivity of TMC catalysts compared to state-of-the-art catalysts ${ }^{48-51,54-57}$.

Furthermore, we performed a comparative mechanistic study by calculating Tafel slopes for different products to gain insight about the $\mathrm{eCO}_{2} \mathrm{RR}$ mechanism of the TMCs i.e., $\mathrm{W}_{2} \mathrm{C}, \mathrm{Mo}_{2} \mathrm{C}$, $\mathrm{Nb}_{2} \mathrm{C}$, and $\mathrm{V}_{2} \mathrm{C}$ NFs in the two-compartment three-electrode electrochemical cell (Supplementary section 6 and Supplementary Fig. 8) ${ }^{58}$. Our Tafel plot analyses show that the TMC NFs possess steeper Tafel slopes, and therefore a weaker potential dependence compared with $\mathrm{Cu}$ NPs for the formed products (i.e., $\mathrm{CO}, \mathrm{CH}_{4}$, and $\mathrm{C}_{2} \mathrm{H}_{4}$ ) (Supplementary Fig. 8) ${ }^{58}$. The Tafel plot analyses suggest a different $\mathrm{CO}_{2} \mathrm{RR}$ mechanism for TMC NFs than that of $\mathrm{Cu}$ catalysts where $\mathrm{C}-\mathrm{O}$ bond scission is the rate-determining step $^{58}$.

To gain more insight to the remarkable performance of these catalysts for electrocatalytic $\mathrm{CO}_{2} \mathrm{RR}$, the structural and physicochemical properties of TMC NFs were characterized at molecular and atomic scales by performing X-ray diffraction (XRD), X-ray photoelectron spectroscopy (XPS), and scanning transmission electron microscopy (STEM) (Supplementary sections 7-9). At first, we have performed XPS experiments to analyze the surface chemistry of TMC NFs. XPS analysis (Supplementary Fig. 9) indicates that our NF samples contain metallic TMCs, with little or no evident surface oxidation. The results show that the chemical composition of the surface, the empirical formula of $\mathrm{M}_{2} \mathrm{C}$ (M: transition metal, C: Carbide), and the oxidation state of +2 for the transition metals i.e., $\mathrm{W}, \mathrm{Mo}, \mathrm{Nb}$, and $\mathrm{V}$ are similar in all synthesized TMCs (Supplementary section 7). The lattice structure and crystallite size of the TMC NFs were then studied by performing XRD experiments. The XRD pattern of $\mathrm{W}_{2} \mathrm{C}$ NFs shows a sharp peak at $39.91^{\circ}$ along with three pronounced peaks at $34.84^{\circ}, 38.54^{\circ}$, and $52.65^{\circ}$ corresponding to (101), (100), (002), and (102) crystal surfaces of $\mathrm{W}_{2} \mathrm{C}$, respectively. The XRD spectra of the TMCs show all Bragg peaks of $\mathrm{W}_{2} \mathrm{C}, \mathrm{Mo}_{2} \mathrm{C}, \mathrm{Nb}_{2} \mathrm{C}$, and $\mathrm{V}_{2} \mathrm{C}$ $\mathrm{NF}$; verifying their homogenous and pure structures. The XRD results indicate a constant dominant lattice plane of (101) and a similar average crystallite size of $25.4 \pm 5 \mathrm{~nm}$ for all synthesized TMCs (Supplementary Fig. 10) ${ }^{59-61}$.

Furthermore, we performed atomic-scale STEM experiments to study surface atom coordination, crystallite sizes, and dominant plane structures of TMC NFs (Supplementary Figs. 11-18). Figure $2 \mathrm{a}-\mathrm{d}$ shows STEM results of $\mathrm{W}_{2} \mathrm{C}$ NFs. Figure $2 \mathrm{a}, \mathrm{b}$ indicate high-angle annular dark-field (HAADF) image and corresponding fast Fourier transforms (FFT) of $\mathrm{W}_{2} \mathrm{C}$ NFs in the $<101>$ zone axis. The atomic models of the $<101>$ zone axis and bright-field (BF) image of $\mathrm{W}_{2} \mathrm{C}$ NFs are represented in Fig. $2 \mathrm{c}$ and $\mathrm{d}$, respectively. Figure $2 \mathrm{~d}$ indicates the carbon atomic columns in the red box and the intensity profile across the red box region showing that the distance between two carbon atoms is $2.55 \AA$. The STEM results of other TMCs i.e., $\mathrm{Mo}_{2} \mathrm{C}, \mathrm{Nb}_{2} \mathrm{C}$, and $\mathrm{V}_{2} \mathrm{C} \mathrm{NFs}$ are explained in Supplementary section 9. The STEM and XRD results of synthesized TMC NFs confirm that the structure of these materials is a perfect match with the standard $1 \mathrm{~T}$ structure, suggesting a tetragonal symmetry and octahedral coordination of

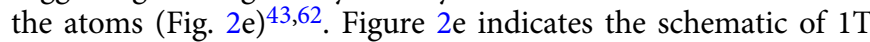
structure TMC NFs showing tetragonal symmetry, one layer per repeat unit with octahedral coordination. The lattice constant $a$ is in the range of 3.07 to $3.15 \AA$ for synthesized TMC NFs. The stacking index $b$ indicates the interlayer spacing which is in the range of 4.53 to $5 \AA$ for studied TMCs. As shown in Fig. 2e, $1 \mathrm{~T}$ atomic coordination provides metal-terminated surface atoms that are known to be favorable binding sites of adsorbed intermediates in $\mathrm{eCO}_{2} \mathrm{RR}^{43,62}$. Our atomic and molecular scale structural analyses indicate that the synthesized TMC NFs have fairly similar structural properties e.g., (1T) crystalline structure with a dominant plane of (101), crystallite sizes, and atomic coordination.

To further discern the difference between the observed electrocatalytic performance of the TMCs, we have studied their electronic properties by performing electrochemical impedance spectroscopy (EIS) (Supplementary section 11) and, work function measurements using ultraviolet photoelectron spectroscopy (UPS) (Supplementary section 12$)^{8}$. At first, we have employed the EIS experiments to compare the overall electron-transfer properties of the TMC catalysts in the double layer region (Supplementary section 11). To do this, TMC NFs with similar structural and physical properties e.g., sizes, shapes, and mass loadings $\left(0.1 \mathrm{mg} / \mathrm{cm}^{2}\right)$ coated on glass carbon were used as the working electrodes. This results in similar roughness, morphology, intrinsic capacitance, and exposed surface area of the studied samples confirmed by our characterization results (Supplementary sections 5-10). The EIS experiments have been performed at a potential of $-310 \mathrm{mV}$ vs RHE for all TMCs under identical experimental conditions (Supplementary section 11). Figure $2 \mathrm{f}$ shows the fitted EIS spectra of each TMC catalyst using Randles circuit model, indicating a smaller charge transfer resistance $\left(\mathrm{R}_{\mathrm{ct}}\right)$ for $\mathrm{W}_{2} \mathrm{C} \mathrm{NFs}(\sim 17 \mathrm{ohm})$ compared to the other TMCs, i.e., $\mathrm{Mo}_{2} \mathrm{C}$ NFs $(\sim 25 \mathrm{ohm}), \mathrm{Nb}_{2} \mathrm{C}$ NFs $(\sim 33 \mathrm{ohm})$, and $\mathrm{V}_{2} \mathrm{C} \mathrm{NFs}(\sim 38$ $\mathrm{ohm})^{63}$. The UPS method also was used to compare the surface work function of TMCs (Fig. $2 \mathrm{~g}$ ). The results indicate a lower work function for $\mathrm{W}_{2} \mathrm{C}$ NFs $(0.2$ to $0.84 \mathrm{eV})$ compared to $\mathrm{Mo}_{2} \mathrm{C}$ NFs (3.92 eV), $\mathrm{Nb}_{2} \mathrm{C} \mathrm{NFs}(4.44 \mathrm{eV})$, and $\mathrm{V}_{2} \mathrm{C} \mathrm{NFs}(4.55 \mathrm{eV})$. The charge transfer resistance obtained by EIS experiments and the surface work function value measured by UPS experiments suggests the superior activity of $\mathrm{W}_{2} \mathrm{C}$ NFs compared to other TMCs in this study i.e., $\mathrm{Mo}_{2} \mathrm{C}, \mathrm{Nb}_{2} \mathrm{C}$, and $\mathrm{V}_{2} \mathrm{C}$ NFs.

In addition to our experimental observations, we have performed density functional theory (DFT) calculations to gain more insight to the electronic and catalytic properties of $\mathrm{M}_{2} \mathrm{C}$ compounds. The aim is to address the enhanced activity and selectivity of these TMCs and to explore both electrochemical (i.e., driven) and chemical (i.e., favorable or spontaneous) processes that distinguish them from other catalysts, such as $\mathrm{Au}$ and $\mathrm{Cu}$.

With respect to activity, the electronic density of states (DOS) indicate that transition metal $d$ states dominate at the Fermi level of these TMCs, much more so than elemental Au, another high 

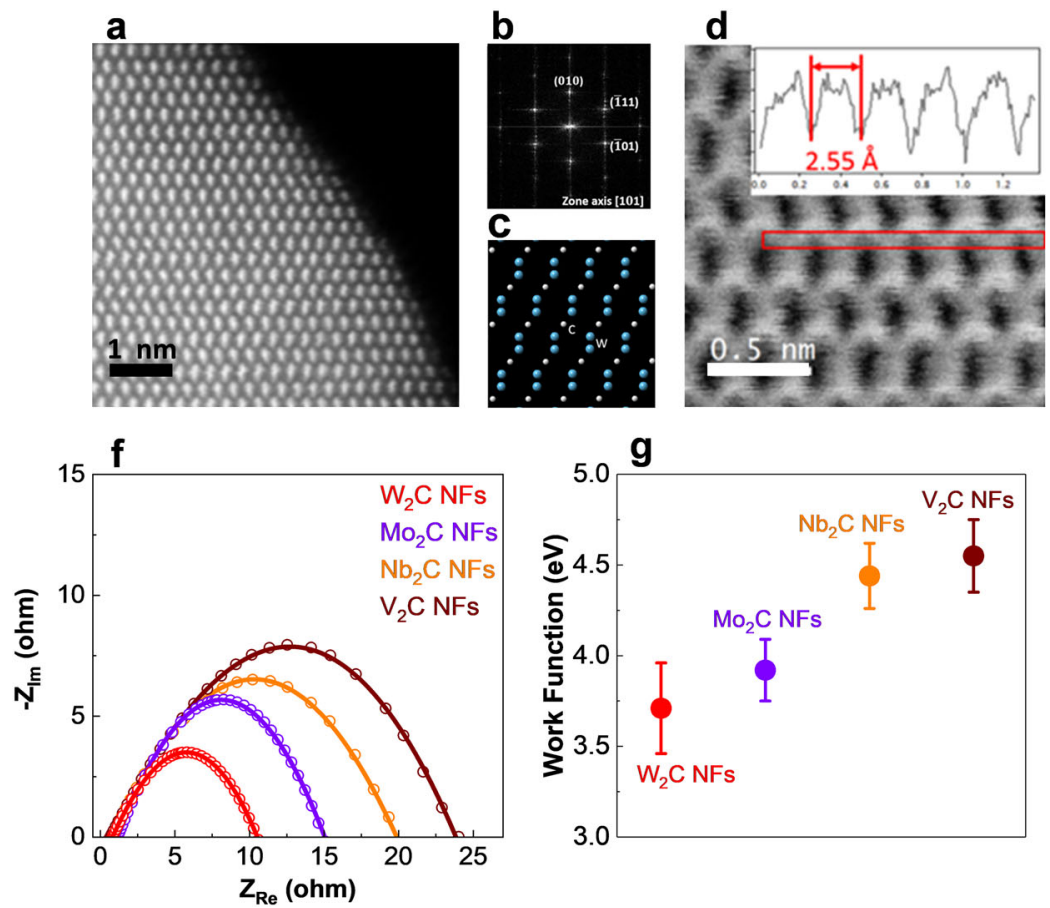

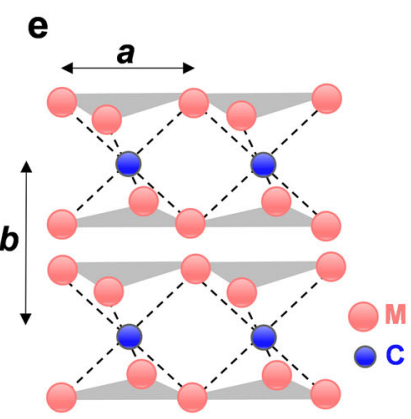

h

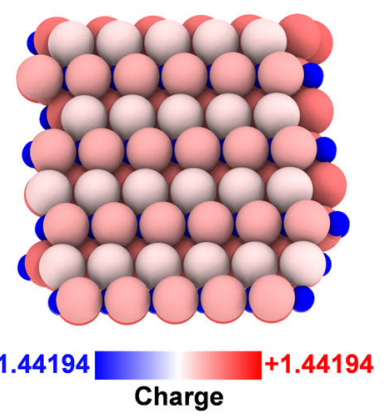

Fig. 2 Structural and electrochemical characterization of TMC catalysts. a High-angle annular dark-field (HAADF) of W $2 \mathrm{C} \mathrm{NFs} \mathrm{in}<101>$ zone axis. $\mathbf{b}$ FFT corresponding to the HAADF image of $\mathrm{W}_{2} \mathrm{C}$ NFs showing the diffraction spots from $<101>$ zone axis. $\mathbf{c}$ Atomic model of $\mathrm{W}_{2} \mathrm{C}$ NFs in $<101>$ zone axis. W atoms are shown as blue and carbon atoms as white spheres. $\mathbf{d}$ Bright field (BF) of $\mathrm{W}_{2} \mathrm{C}$ NFs in $<101>$ zone axis. It shows the carbon atomic columns in a red box. The inset is intensity profile across red box region showing the distance between two carbon atoms is $2.55 \AA$. e Schematic of $1 \mathrm{~T}$ structure TMCs showing tetragonal symmetry, one layer per repeat unit with octahedral coordination. The transition metal atoms ( $\mathrm{W}$, Mo, $\mathrm{Nb}$, and $\mathrm{V}$ ) are red and the carbon atoms are blue. The lattice constant $a$ is in the range of 3.07 to $3.15 \AA$ for synthesized TMCs. The stacking index $b$ indicates the interlayer spacing which is in the range of 4.53 to $5 \AA$ for studied TMCs. f Electrochemical impedance spectroscopy (EIS) for studied catalysts at a potential of -310 m $V$ vs $\mathrm{RHE}$ in the two-compartment three-electrode electrochemical cell using $\mathrm{KOH}: \mathrm{CC}(3 \mathrm{M}: 2 \mathrm{M}$ ) electrolyte. $\mathbf{g}$ Work function measurements for synthesized TMCs using ultraviolet photoelectron spectroscopy (UPS) method. $\mathbf{h}$ Bader charges of $\mathrm{W}_{2} \mathrm{C}$ NFs indicate that surface W-atoms are contributing significantly to the catalytic activity of the $\mathrm{W}_{2} \mathrm{C}$ (101) surface.

activity catalyst. Bader charge calculations indicate that metal atoms at the TMC surface are significantly more reduced compared to the bulk atoms (Fig. $2 \mathrm{~h}$ and Supplementary Fig. 24). These results indicate the increased availability of electrons at metal-rich TMC surfaces, which may increase the catalytic activity of TMC NFs.

With respect to the increased selectivity of TMC NFs, especially for $\mathrm{CH}_{4}$ production, we have explored the $\mathrm{CO}_{2} \mathrm{RR}$ pathway on the $\mathrm{W}_{2} \mathrm{C}$ (101) surface in detail by using DFT calculations. Focusing initially on electrochemical processes, we employed the computational hydrogen electrode (CHE) model ${ }^{64-66}$ (Supplementary Tables 7-10) to explore the stepwise electronic reduction and protonation of adsorbed species in the low molecular coverage limit. The lowest free energy pathway to produce $\mathrm{CH}_{4}$ with only electrochemical steps is shown in Fig. 3 and Supplementary Fig. 27. The same steps with only a slight adjustment for experimental Faradaic efficiencies at the potential for optimal $\mathrm{CH}_{4}$ production is provided in Supplementary Fig. 26).

This pathway indicates that limiting steps (at zero potential with respect to $\mathrm{RHE}$ ) are protonation of adsorbed $\mathrm{CO}_{2}$ and $\mathrm{O}$, and, most importantly, the desorption of $\mathrm{H}_{2} \mathrm{O}$ following protonation of adsorbed $\mathrm{OH}$. The difficulty of this final step is not surprising, as $\mathrm{W}_{2} \mathrm{C}$ (101) strongly adsorbs and spontaneously dissociates water $\left(\mathrm{H}_{2} \mathrm{O} \rightarrow \mathrm{H}^{*}+\mathrm{OH}^{*}, \triangle G=-1.797 \mathrm{eV}\right)$ without electrochemical assistance. Similarly, our calculations indicate that $\mathrm{W}_{2} \mathrm{C}$ (101) strongly chemisorbs $\mathrm{CO}_{2}\left(\mathrm{CO}_{2} \rightarrow \mathrm{CO}_{2}^{*}, \triangle G=-1.24 \mathrm{eV}\right.$, bond length $d(W-O)=2.04 \AA, d(W-C)=2.12 \AA)$ in contrast to normally weak physisorption on $\mathrm{Cu}(-0.3 \mathrm{eV})$ and other catalyst surfaces ${ }^{28,67-69}$. Furthermore, the (101) surface of $\mathrm{W}_{2} \mathrm{C}$ enables favorable and unassisted dissociation of adsorbed $\mathrm{CO}_{2}$ $\left(\mathrm{CO}_{2}^{*} \rightarrow \mathrm{CO}^{*}+\mathrm{O}^{*}, \triangle G=-0.97 \mathrm{eV}\right.$, Supplementary Table 10) suggesting that $\mathrm{C}-\mathrm{O}$ bond scission may take place in the early stages of $\mathrm{CO}_{2}$ reduction, skipping the uphill production of adsorbed carboxyl. Based on these findings, we propose that $\mathrm{W}_{2} \mathrm{C}$ (101) distinguishes itself as a catalyst due to an interplay between surfaceassisted chemical steps, whose energetics will depend on the local chemical equilibrium at the surface and electrochemical steps that reduce preexisting surface reagents and open up new pathways for the overall reaction to proceed. More detailed studies of such cooperative catalytic processes and their limiting steps may be encouraged based on the promise of $\mathrm{W}_{2} \mathrm{C}$ as a high-performance $\mathrm{CO}_{2}$ reduction catalyst. Here, we highlight the plausible cooperative effects of these steps, which set apart $\mathrm{W}_{2} \mathrm{C}$ from conventional noble metal catalysts and the other TMCs, specially for $\mathrm{CH}_{4}$ production. The immediate benefit of the favorable chemical processes mentioned above should be a higher surface coverage of $\mathrm{CO}_{2}$ (and consequently $\mathrm{CO}$ ) and an excess of surface protons. This may explain the high Faradaic efficiencies for the production of both $\mathrm{H}_{2}$ and $\mathrm{CO}$ at low potentials (see Supplementary section 3 and Supplementary Table 1). However, once a limiting potential $(-0.74 \mathrm{~V}$ estimate $)$ is reached, the readily protonated products of adsorbed $\mathrm{CO}$ that produce $\mathrm{CH}_{4}$ are no longer hindered by a buildup of adsorbed byproducts $\left(\mathrm{O}^{*}\right.$ then $\left.\mathrm{OH}^{*}\right)$, which can now be protonated and released from the surface.

We can divide the complex, multistep reaction into two key parts: initial conversion of adsorbed $\mathrm{CO}_{2}$ to adsorbed $\mathrm{CO}$, followed by conversion of adsorbed $\mathrm{CO}$ to $\mathrm{CH}_{4}$ with the release of $\mathrm{H}_{2} \mathrm{O}$ (see Fig. 3 and Supplementary Fig. 27). As indicated in 


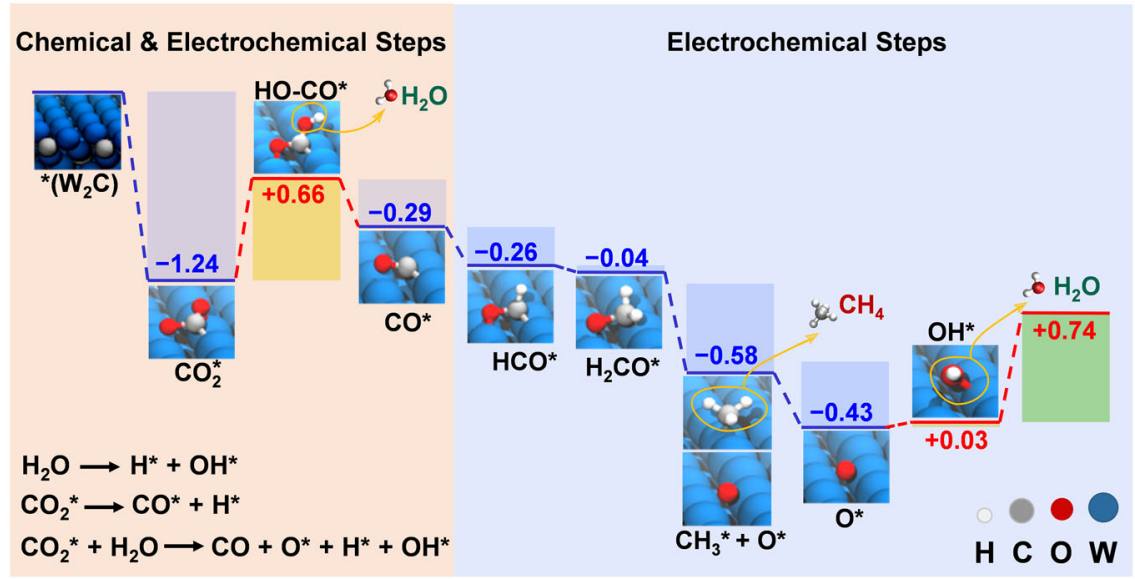

Fig. 3 Minimum energy path for the electrochemical $\mathbf{C O}_{\mathbf{2}}$ conversion into $\mathbf{C H}_{\mathbf{4}}$ on the surface of $\mathbf{W}_{\mathbf{2}} \mathbf{C} \mathbf{N F s}$. Only electrochemical steps are shown. The parts of the reaction where chemical and electrochemical steps are essential are highlighted by colors. The favorable reactions of key chemical steps are provided (for free energies of these reactions, see Table S9). The intermediates are indicated. Gibbs free energies for reaction at zero potential vs RHE are given in $\mathrm{eV}$.

Fig. 3, the first part, generation of adsorbed CO, can be achieved by chemical or electrochemical means. We have direct and favorable chemical conversion of adsorbed $\mathrm{CO}_{2}$ to adsorbed $\mathrm{CO}$ and $\mathrm{O}$ on $\mathrm{W}_{2} \mathrm{C}(101)$, but also two electrochemical pathways: production of $\mathrm{HO}-\mathrm{CO}^{*}$ in a single step $(+0.66 \mathrm{eV}$, Fig. 3) or an alternative initially favorable protonation to $\mathrm{OCHO}^{*}$ followed by two uphill electrochemical steps producing the first $\mathrm{OCH}_{2} \mathrm{O}^{*}$ followed by the release of $\mathrm{H}_{2}$ and the final product of $\mathrm{HO}-\mathrm{CO}^{*}$ with a similar free energy cost $(+0.68 \mathrm{eV}$, Supplementary Fig. 27 and Supplementary Table 10). A final electrochemically driven protonation of $\mathrm{HO}-\mathrm{CO}^{*}$ favorably releases $\mathrm{H}_{2} \mathrm{O}$ and leaves $\mathrm{CO}^{*}$.

With chemically or electrochemically generated adsorbed $\mathrm{CO}$, we can proceed to the second part of the overall reaction to produce $\mathrm{CH}_{4}$ from $\mathrm{CO}_{2}$, which involves multiple favorable protonation steps. The $\mathrm{W}_{2} \mathrm{C}$ catalyst distinguishes itself here. The electrochemical activation of $\mathrm{CO}^{*} \rightarrow \mathrm{HCO}^{*}$ remains thermodynamically favorable $(\Delta \mathrm{G}=-0.26 \mathrm{eV})$ on $\mathrm{W}_{2} \mathrm{C}$ (101), whereas on other catalysts, such as $\mathrm{Cu}$, this process is usually uphill with the potential ranging from -0.74 to $-0.97 \mathrm{~V}$ vs $\mathrm{RHE}^{66,70}$. Moreover, due to the spontaneous water dissociation, the direct $\mathrm{H}^{*}$ transfer step $\mathrm{CO}^{*}+\mathrm{H}^{*} \rightarrow \mathrm{HCO}^{*}$ on $\mathrm{W}_{2} \mathrm{C}$ could be even more favorable with a resultant $\Delta \mathrm{G}=-0.433 \mathrm{eV}$ (Supplementary Table 10). The next two electrochemical steps are downhill $(\Delta \mathrm{G}=-0.04$ and $-0.58 \mathrm{eV})$ : the first forming the unstable methoxy radical $\mathrm{CH}_{3} \mathrm{O}^{*}$ with oxygen attached to a surface $\mathrm{W}$ atom; the second leading to spontaneous dissociation into the methyl radical $\mathrm{CH}_{3}^{*}$ and a surface oxygen atom $\mathrm{O}^{*}$. The electrochemical conversion of the surface $\mathrm{CH}_{3}^{*}$ into $\mathrm{CH}_{4}$ is favorable $\left(\Delta \mathrm{G}=-0.43 \mathrm{eV}\right.$ ) and the protonation of the surface oxygen $\mathrm{O}^{*}$ is only slightly uphill $(\Delta \mathrm{G}=+0.03 \mathrm{eV})$. As we already stated, for the overall reaction $\mathrm{CO}_{2}^{*}+8 \mathrm{H}^{+} / e^{-} \rightarrow *+2 \mathrm{H}_{2} \mathrm{O}+\mathrm{CH}_{4}$ on $\mathrm{W}_{2} \mathrm{C}$ (101) it is the final protonation of $\mathrm{OH}^{*}$ to release $\mathrm{H}_{2} \mathrm{O}$ that is the limiting step $(\Delta \mathrm{G}=+0.74 \mathrm{eV})$.

We also compared $\mathrm{W}_{2} \mathrm{C}$ with the other TMCs studied by calculating the energies of adsorption of water and $\mathrm{CO}_{2}$ as well as the potentials of the rate-determining step (i.e., protonation of $\mathrm{OH}^{*}$ ) for $\mathrm{Nb}_{2} \mathrm{C}, \mathrm{Mo}_{2} \mathrm{C}$, and $\mathrm{V}_{2} \mathrm{C}$ (Supplementary Table 11). Our calculations indicate that these TMCs also strongly chemisorb $\mathrm{CO}_{2}$ with adsorption energies of $-1.32,-1.62$, and $-0.96 \mathrm{eV}$, respectively. Moreover, $\mathrm{Nb}_{2} \mathrm{C}$ also shows favorable $\mathrm{C}-\mathrm{O}$ bond scission of adsorbed $\mathrm{CO}_{2}$. Additionally, $\mathrm{Nb}_{2} \mathrm{C}, \mathrm{Mo}_{2} \mathrm{C}$, and $\mathrm{V}_{2} \mathrm{C}$ strongly adsorb water with the energies of $-1.87,-1.23$, and $-0.59 \mathrm{eV}$, respectively, where $\mathrm{Nb}_{2} \mathrm{C}$ is the only other catalyst that dissociates water. In contrast to $\mathrm{W}_{2} \mathrm{C}$, the energies required for the protonation of $\mathrm{OH}^{*}$ are higher: $+1.17,+1.25$, and $+0.85 \mathrm{eV}$ for $\mathrm{Nb}_{2} \mathrm{C}, \mathrm{Mo}_{2} \mathrm{C}$, and $\mathrm{V}_{2} \mathrm{C}$, respectively (Supplementary Table 11). Therefore, we can conclude that, within this set of four TMCs, $\mathrm{W}_{2} \mathrm{C}$ possesses the optimal characteristics for efficient completion of $\mathrm{CO}_{2} \mathrm{RR}$ : (1) sufficiently strong adsorption of $\mathrm{CO}_{2}$, (2) spontaneous dissociation of water, and (3) the lowest limiting potential for $\mathrm{OH}^{*}$ protonation. We conclude that the performance of $\mathrm{Nb}_{2} \mathrm{C}$ is reduced due to its stronger water adsorption, resulting in the protonation of $\mathrm{OH}^{*}$ requiring more energy. We would expect $\mathrm{Mo}_{2} \mathrm{C}$ to have a lower surface coverage of protons and higher costs for the protonation of $\mathrm{OH}^{*}$. The weakest $\mathrm{CO}_{2}$ adsorption on $\mathrm{V}_{2} \mathrm{C}$ decreases its surface coverage, making it the worst TMC catalyst here, despite its relatively small limiting reaction potential of protonation of $\mathrm{OH}^{*}$.

As we mentioned before, for $\mathrm{W}_{2} \mathrm{C}$ the realistic network of pathways towards $\mathrm{CH}_{4}$ consists of a potential-dependent combination of competing chemical and electrochemical steps with the actual limiting potential being in the range from -0.483 to $-0.744 \mathrm{~V}$ vs RHE (see the full path. Supplementary Fig. 27), which is consistent with our three-electrode electrochemical experimental results (Supplementary section 3 and Supplementary Table 1). A steeper Tafel slope for $\mathrm{CH}_{4}$ formation on $\mathrm{W}_{2} \mathrm{C}$ than other TMCs and $\mathrm{Cu}$, (Supplementary Fig. 8) also indicates the competition between reactions for the active sites on the catalyst surface. Specifically, the spontaneous water dissociation on $\mathrm{W}_{2} \mathrm{C}$ (101) explains the ease of the HER in our nonacidic electrolyte where the source of protons is normally water. A weak potential dependence of the partial CO current and its small overpotential also originate from the interplay between chemical and electrochemical steps (see Supplementary Information for details).

Experimentally, we have studied the effect of CC on the activity and selectivity of the TMC catalysts. To do this, we have performed electrochemical $\mathrm{CO}_{2} \mathrm{RR}$ in different $\mathrm{CC}$ concentrations of i.e., $0.01,0.1,1$, and $2 \mathrm{M}$ mixed with $3 \mathrm{M} \mathrm{KOH}$ (Supplementary section 14). Figure 4 shows $\mathrm{CO}_{2} \mathrm{RR}$ overall current density and different products (i.e., $\mathrm{CH}_{4}, \mathrm{C}_{2} \mathrm{H}_{4}, \mathrm{CO}$, alcohols$\mathrm{CH}_{3} \mathrm{OH}$, and $\mathrm{C}_{2} \mathrm{H}_{5} \mathrm{OH}$ - and $\mathrm{H}_{2}$ ) partial current densities for $\mathrm{W}_{2} \mathrm{C}$ NFs in different $\mathrm{CC}$ concentration electrolytes. Figure $4 \mathrm{a}$ indicates that by increasing the concentration of $\mathrm{CC}$ in the electrolyte the $\mathrm{CO}_{2} \mathrm{RR}$ current density $\left(j_{\mathrm{CO} 2 \mathrm{RR}}\right)$ increases and reaches a maximum value of $-548.89 \mathrm{~mA} / \mathrm{cm}^{2}$ at a potential of 

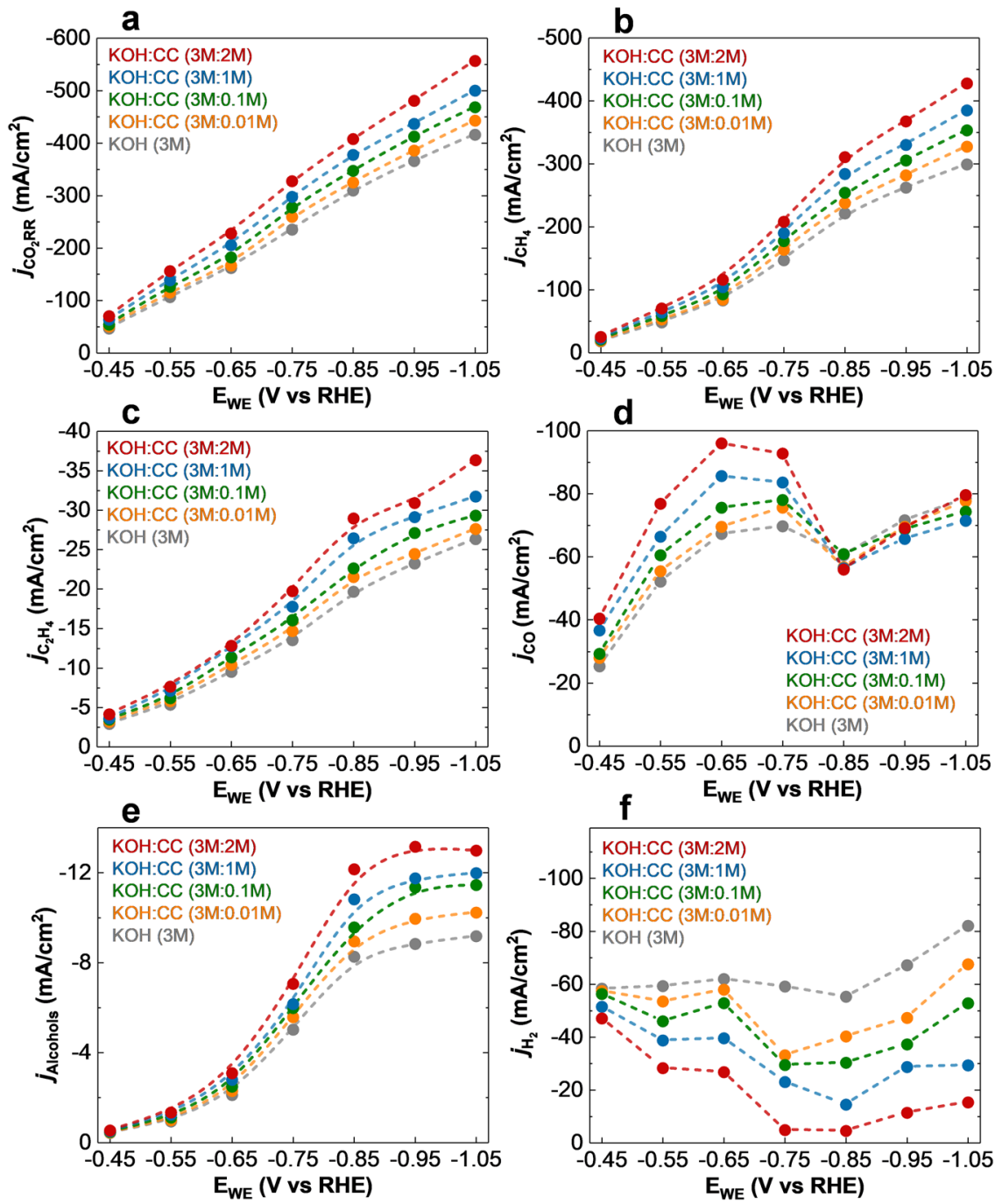

Fig. 4 Effect of choline chloride in the electrochemical performance of $\mathbf{W}_{2} \mathbf{C N F s}$ for $\mathrm{CO}_{2} R R$. The values are measured using $3 \mathbf{M}$ KOH and mixed $3 \mathbf{M}$ KOH with different concentrations $(\mathbf{0 . 1}, \mathbf{0 . 0 1}, \mathbf{1}$, and $\mathbf{2} \mathbf{M})$ of choline chloride $\mathbf{( C C )}$ electrolytes. Partial current density $(j)$ measurements for a $\mathrm{CO}_{2} \mathrm{RR}_{\text {, }}$ b $\mathrm{CH}_{4}, \mathbf{c} \mathrm{C}_{2} \mathrm{H}_{4}$, d $\mathrm{CO}$, e Alcohols $\left(\mathrm{CH}_{3} \mathrm{OH}\right.$ and $\left.\mathrm{C}_{2} \mathrm{H}_{5} \mathrm{OH}\right)$, and $\mathbf{f} \mathrm{H}_{2}$ as a function of potential $\left(\mathrm{E}_{W E}\right)$.

$-1.05 \mathrm{~V}$ vs RHE for $2 \mathrm{M}$ of CC. The obtained value is about 32 , 24 , and $17,9 \%$ higher than that of $0,0.01,0.1$, and $1 \mathrm{M}$ of $\mathrm{CC}$, respectively. Moreover, a maximum $\mathrm{CH}_{4}$ formation current density $\left(j_{\mathrm{CH} 4}\right)$ of $-421.63 \mathrm{~mA} / \mathrm{cm}^{2}$ is obtained for $2 \mathrm{M} \mathrm{CC}$ at a potential of $-1.05 \mathrm{~V}$ vs RHE that is about $1.41,1.29,1.19$, and 1.1 times higher than that of $0,0.01,0.1$, and $1 \mathrm{M}$, respectively (Fig. 4b).

The results also indicate using $\mathrm{W}_{2} \mathrm{C}$ NFs, maximum partial current densities of other products i.e., $\mathrm{C}_{2} \mathrm{H}_{4} \quad\left(j_{\mathrm{C} 2 \mathrm{H} 4}\right.$ of $\left.-35.84 \mathrm{~mA} / \mathrm{cm}^{2}\right), \mathrm{CO}\left(j_{\mathrm{CO}}\right.$ of $\left.-78.48 \mathrm{~mA} / \mathrm{cm}^{2}\right)$, and alcohols $\left(j_{\text {Alcohols }}\right.$ of $-12.81 \mathrm{~mA} / \mathrm{cm}^{2} ;-6.84 \mathrm{~mA} / \mathrm{cm}^{2}$ for $\mathrm{CH}_{3} \mathrm{OH}$ and $-5.97 \mathrm{~mA} / \mathrm{cm}^{2}$ for $\left.\mathrm{C}_{2} \mathrm{H}_{5} \mathrm{OH}\right)$ were obtained at the potential of $-1.05 \mathrm{~V}$ vs RHE in $2 \mathrm{M}$ CC (Fig. $4 \mathrm{~b}-\mathrm{d}$ ). In contrast, the measured $\mathrm{H}_{2}$ partial current densities indicate that by adding a higher concentration of CC to the electrolyte solution the rate of $\mathrm{H}_{2}$ production decreases significantly where a minimum $\mathrm{H}_{2}$ formation current density of $-4.48 \mathrm{~mA} / \mathrm{cm}^{2}$ was obtained for $2 \mathrm{M} \mathrm{CC}$ at a potential of $-0.85 \mathrm{~V}$ vs $\mathrm{RHE}$ that is $12.31,8.97,6.76,3.23$ times lower than that of $0,0.01,0.1$ and $1 \mathrm{M}$ CC, respectively.

These results suggest that adding $\mathrm{CC}$ to the $3 \mathrm{M} \mathrm{KOH}$ electrolyte suppresses the competing HER and increases the formation of $\mathrm{CO}_{2} \mathrm{RR}$ products more specifically $\mathrm{CH}_{4}{ }^{27}$.
The stability of the CC electrolytes was studied by conducting nuclear magnetic resonance (NMR) and ${ }^{13} \mathrm{CO}_{2}$ isotope experiments (Supplementary sections 15 and 16$)^{27,46,71}$. The ${ }^{1} \mathrm{H}$ and ${ }^{13} \mathrm{C}$ NMR spectra reveal similar peak areas and chemical shifts for fresh and used electrolytes indicating no generation of new diamagnetic species or change in the CC structure under an applied potential of $-1.05 \mathrm{~V}$ vs RHE (Supplementary Figs. 38, 39). The ${ }^{13} \mathrm{CO}_{2}$ isotope experiments also show that the $\mathrm{CO}_{2}$ gas present inside the electrolyte is the only source of the formed products in the electrochemical $\mathrm{CO}_{2} \mathrm{RR}$ (Supplementary Fig. 41). These results confirm that $\mathrm{CC}$ with different concentrations i.e., 0,01 , $0.1,1$, and $2 \mathrm{M}$ remains stable at the range of applied potentials in the electrochemical $\mathrm{CO}_{2} \mathrm{RR}$ experiments.

Next, we studied the performance of $\mathrm{W}_{2} \mathrm{C}$ NFs in our developed solid polymer electrolyte flow electrolyzer for continuous electrochemical $\mathrm{CO}_{2} \mathrm{RR}$ using this catalyst as the cathode (Supplementary section 17). The flow electrolyzer used in this study consists of a two-compartment electrochemical setup with an active area of $5 \mathrm{~cm}^{2}$ coated with $\mathrm{W}_{2} \mathrm{C} \mathrm{NFs}$ at the cathode and iridium oxide nanoparticles ( $\mathrm{IrO}_{2} \mathrm{NPs}$ ) as the anode and were then fed with humidified $\mathrm{CO}_{2}$ and $\mathrm{KOH}: \mathrm{CC}(3 \mathrm{M}: 2 \mathrm{M})$ electrolyte, respectively (Supplementary section 17 ). 

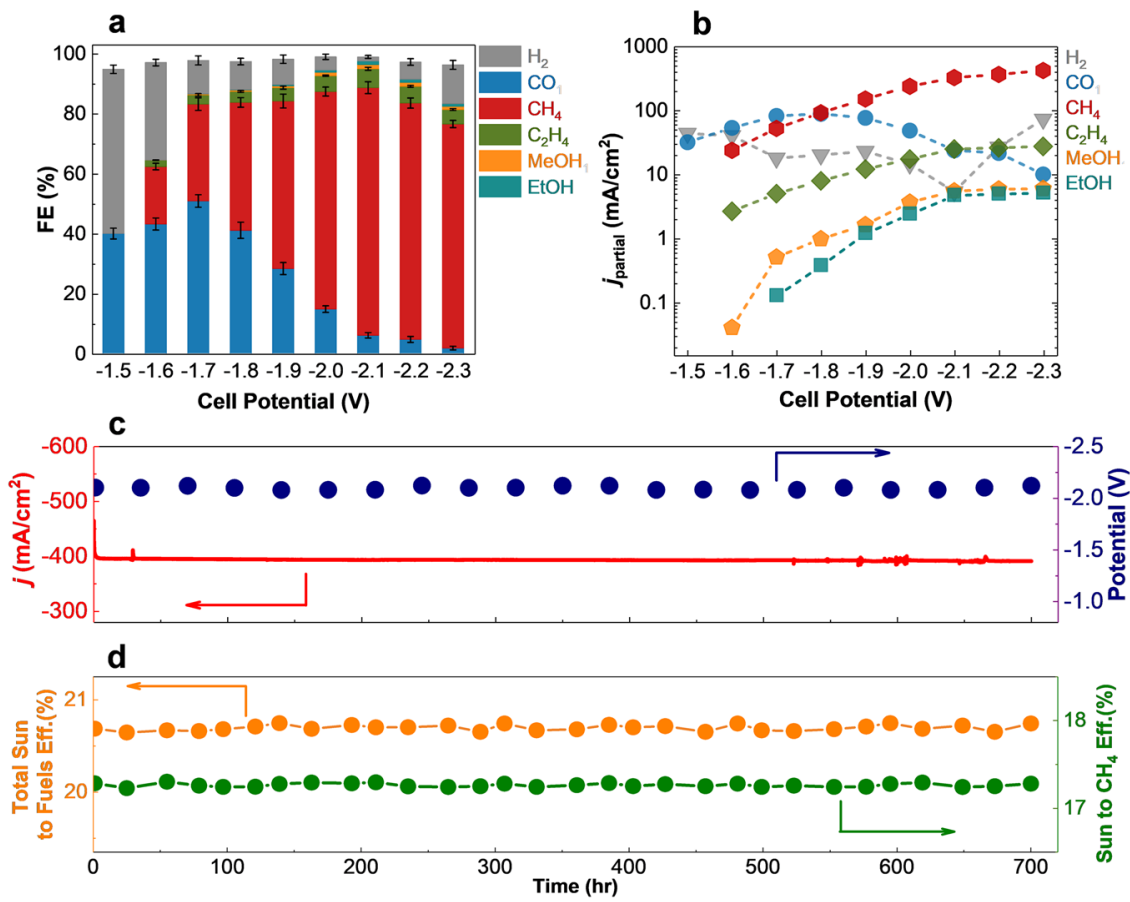

Fig. 5 Electrocatalytic performance and stability of $\mathbf{W}_{\mathbf{2}} \mathbf{C} \mathbf{N F s}$ in the solid polymer electrolyte flow electrolyzer. a Faradaic efficiency (FE) measurements of $\mathrm{H}_{2}, \mathrm{CO}, \mathrm{CH}_{4}, \mathrm{C}_{2} \mathrm{H}_{4}$, methanol $(\mathrm{MeOH})$, and ethanol (EtOH) for $\mathrm{W}_{2} \mathrm{C} \mathrm{NFs}$ at different cell potentials. The error bars represent standard deviations of four independent experiments. $\mathbf{b}$ Partial current density for each product as a function of cell potential. The values are obtained considering the total current density and faradaic efficiencies of products at the entire range of cell potential. c Measured total current densities and cell potentials of the solar-driven solid polymer electrolyte flow electrolyzer under one sun illumination provided by the TJ-PV cell over time. $\mathbf{d}$ Total sun to fuels efficiency and sun to $\mathrm{CH}_{4}$ production efficiency in the solar-driven solid polymer electrolyte flow electrolyzer over time.

To study the $\mathrm{CO}_{2} \mathrm{RR}$ performance of $\mathrm{W}_{2} \mathrm{C}$ NFs in the flow electrolyzer, we performed chronoamperometry (CA) experiments at different cell potentials ranging from -1.5 to $-2.3 \mathrm{~V}$ for $\mathrm{W}_{2} \mathrm{C}$ NFs (Supplementary section 17). As shown in Fig. 5a, the results show that at a cell potential of $-1.5 \mathrm{~V}$, hydrogen $\left(\mathrm{H}_{2}, \mathrm{FE}\right.$ of $54.9 \% \pm 1.4$ ) and $\mathrm{CO}(\mathrm{FE}$ of $40.1 \% \pm 1.8$ ) are the dominant products. However, our measurements indicate that by increasing the cell potential a system becomes more selective for $\mathrm{CH}_{4}$ formation with the maximum $\mathrm{FE}$ of $82.7 \% \pm 2$ at a cell potential of $-2.1 \mathrm{~V}$. At this potential, $\mathrm{W}_{2} \mathrm{C}$ NFs slightly produce other products such as $\mathrm{C}_{2} \mathrm{H}_{4}, \mathrm{CH}_{3} \mathrm{OH}, \mathrm{C}_{2} \mathrm{H}_{5} \mathrm{OH}, \mathrm{CO}$, and $\mathrm{H}_{2}$ with FEs of $5.6,1.4,1.2,6.1$, and 1.4 , respectively. Figure $5 \mathrm{~b}$ shows the maximum $\mathrm{CH}_{4}, \mathrm{C}_{2} \mathrm{H}_{4}, \mathrm{CH}_{3} \mathrm{OH}$, and $\mathrm{C}_{2} \mathrm{H}_{5} \mathrm{OH}$ current densities of $-421.28,-27.31,-5.95$, and $-5.19 \mathrm{~mA} / \mathrm{cm}^{2}$ at the cell potential of $-2.3 \mathrm{~V}$, respectively, confirming high selectivity of $\mathrm{W}_{2} \mathrm{C}$ NFs towards $\mathrm{CH}_{4}$ as the main product.

Next, we coupled the electrolyzer to a triple junction photovoltaic (TJ-PV) cell with a maximum efficiency of $34.3 \%$ to determine the $\mathrm{CO}_{2} \mathrm{RR}$ performance and energy efficiency of $\mathrm{W}_{2} \mathrm{C}$ NFs in a solar-driven device (Supplementary section 18). The j-V characteristic curve of the TJ-PV cell under one sun illumination $\left(100 \mathrm{~mW} / \mathrm{cm}^{2}\right)$ using a sun simulator light source is shown in Supplementary Fig. 48. The operating point is chosen to provide a photocurrent density of $-394.3 \mathrm{~mA} / \mathrm{cm}^{2}$ at a potential of $-2.1 \mathrm{~V}$ which has the maximum $\mathrm{FE}$ of $\mathrm{CH}_{4}(82.7 \% \pm 2)$ calculated in the flow electrolyzer (Supplementary Fig. 49).

Figure $5 \mathrm{c}$ shows the current density of the solar-driven electrolyzer for a $700-\mathrm{h}$ continuous process at a potential of $-2.1 \mathrm{~V}$. The results shown in Fig. $5 \mathrm{c}$ indicate a negligible decrease ( 2\%) in the photocurrent density of $\mathrm{W}_{2} \mathrm{C}$ NFs over the 700-h experiment while the corresponding photo-potential fluctuates between -2.08 to $-2.12 \mathrm{~V}$, confirming the high stability of $\mathrm{W}_{2} \mathrm{C}$ NFs for $\mathrm{CO}_{2} \mathrm{RR}$.
The measured sun to $\mathrm{CO}_{2} \mathrm{RR}$ products $\left(\mathrm{CO}, \mathrm{CH}_{4}, \mathrm{C}_{2} \mathrm{H}_{4}\right.$, $\mathrm{CH}_{3} \mathrm{OH}$, and $\mathrm{C}_{2} \mathrm{H}_{5} \mathrm{OH}$ ) as well as total solar-to-fuel efficiency (SFE) of $\mathrm{W}_{2} \mathrm{C}$ NFs over a 700-h process are shown in Fig. $5 \mathrm{~d}$ (Supplementary section 18). As shown in this figure, an average sun to the $\mathrm{CH}_{4}$ production efficiency of $17.3 \%$ with negligible variation (2\%) is achieved during the $700-\mathrm{h}$ continuous process. Considering other products, $\mathrm{W}_{2} \mathrm{C}$ NFs show an SFE of $20.7 \%$.

We also calculated the energy efficiency of $\mathrm{CO}_{2} \mathrm{RR}$ in our developed flow electrolyzer and compared it with state-ofthe-art catalytic systems in the literature (Supplementary section 17$)^{29,30,37,57,72}$. As shown in this figure (Supplementary Fig. 47), the maximum energy efficiency of $62.3 \%$ was obtained for our developed flow electrolyzer using $\mathrm{W}_{2} \mathrm{C}$ catalyst that is about 67 and $73 \%$ more efficient than $\mathrm{Cu}_{\mathrm{oh}}(37.4 \%)^{50}$ and recently developed $\mathrm{Cu}-\mathrm{CIPH}(36.1 \%)^{72}$ catalytic systems, respectively.

In summary, we have synthesized four members of TMCs with a formula of $\mathrm{M}_{2} \mathrm{C}$, i.e., $\mathrm{W}_{2} \mathrm{C}, \mathrm{Mo}_{2} \mathrm{C}, \mathrm{Nb}_{2} \mathrm{C}$, and $\mathrm{V}_{2} \mathrm{C} \mathrm{NFs}$ using the carburization method followed by the liquid exfoliation technique and tested their catalytic performance for $\mathrm{eCO}_{2} \mathrm{RR}$ in $\mathrm{KOH}: \mathrm{CC}$ (3 M:2 M) electrolyte. The electrocatalytic performance studies of TMCs shows these materials are mainly selective for $\mathrm{CH}_{4}$ formation with $\mathrm{W}_{2} \mathrm{C}$ NFs having the best $\mathrm{CO}_{2} \mathrm{RR}$ activity compared to the studied catalysts. For instance, a $\mathrm{CO}_{2} \mathrm{RR}$ current density of $-548.89 \mathrm{~mA} / \mathrm{cm}^{2}$ and a maximum $\mathrm{CH}_{4}$ current density of $-421.63 \mathrm{~mA} / \mathrm{cm}^{2}$ at the potential of $-1.05 \mathrm{~V}$ vs RHE were observed for $\mathrm{W}_{2} \mathrm{C}$ NFs. Our electrochemical results also indicate that adding CC to the electrolyte enhances the formation of $\mathrm{CO}_{2} \mathrm{RR}$ products by suppressing the HER for all studied TMCs. Moreover, the NMR and ${ }^{13} \mathrm{CO}_{2}$ isotope experiments confirm that the $\mathrm{CC}$ remains stable during the electrochemical experiments. Atomic and molecular scale characterizations such as XPS, XRD, and STEM indicate that all synthesized TMCs have a similar 
lattice structure of $1 \mathrm{~T}$ with a dominant plane of (101) and almost the same average crystallite size of $25.4 \mathrm{~nm}$. Furthermore, the electronic property analyses of TMCs reveal superior electronic properties of $\mathrm{W}_{2} \mathrm{C}$ NFs: low work function; small charge transfer resistance in the electrochemical double layer region; and heavily reduced tungsten atoms at the surface, which may lead to the observed high activity. Computational results also indicate that the studied TMCs spontaneously chemisorb $\mathrm{CO}_{2}$ and water as compared to $\mathrm{Cu}$. However, among the TMCs studied, $\mathrm{W}_{2} \mathrm{C}$ exhibits the optimal combination for $\mathrm{CH}_{4}$ production, with favorable adsorption energies of water and $\mathrm{CO}_{2}$ coupled with spontaneous dissociation, and less costly protonation of $\mathrm{OH}^{*}$, which is the limiting step, with a low limiting potential in the range of -0.483 to $-0.744 \mathrm{~V}$ vs RHE. Using $\mathrm{W}_{2} \mathrm{C}$ NFs, we have demonstrated a solar-driven flow electrolyzer that can work up to $700 \mathrm{~h}$ with a solar to $\mathrm{CH}_{4}$ efficiency and a total SFE of 17.3 and $20.7 \%$, respectively, under one sun illumination. The demonstrated solar-driven flow electrolyzer using a non-precious metal catalyst $\left(\mathrm{W}_{2} \mathrm{C} \mathrm{NFs}\right)$ in this study achieves maximum efficiency of $62.3 \%$ making it a good candidate to approach the commercially relevant electrocatalytic $\mathrm{CO}_{2} \mathrm{RR}$. This opens a new direction toward a low-cost, sustainable large-scale production of fuels from $\mathrm{CO}_{2}$ that can be used any time any place.

\section{Methods}

Synthesis of TMCs. TMCs were prepared by carburization process in a dual-zone tubular furnace with a controlled flow of $\mathrm{CH}_{4}$ and $\mathrm{H}_{2}$ mixture (volumetric ratio $\mathrm{CH}_{4}: \mathrm{H}_{2}$ of 1:9) at a temperature of $973 \mathrm{~K}$. The obtained bulk powders were then collected and ground to fine powders in a mortar and pestle. Next, a certain amount of TMC powders were processed in isopropyl alcohol using an ultrasonic liquid processor (Sonics VibraCell VCX-130) to obtain a solution of TMC NFs. The resulting solution was further centrifuged and the top two-third of the solutions were collected and stored as the TMCs in a vial for cathode electrode preparation. A detailed explanation is provided in Supplementary section 1.

Electrochemical setup. A two-compartment three-electrode electrochemical cell was used to perform the fundamental study for cathodic half-cell reaction using the synthesized $\mathrm{W}_{2} \mathrm{C}, \mathrm{Mo}_{2} \mathrm{C}, \mathrm{Nb}_{2} \mathrm{C}$, and $\mathrm{V}_{2} \mathrm{C}$ NFs and compared them with $\mathrm{Au}$ and $\mathrm{Cu}$ NPs. In the three-electrode cell study, the working electrode was prepared by dropcasting the catalysts (mass loading of $0.1 \mathrm{mg}$ ) on a glassy carbon electrode with a geometric surface area of $1 \mathrm{~cm}^{2}$. The catalyst loading on the electrode was precisely controlled to be $0.1 \mathrm{mg} / \mathrm{cm}^{2}$ on the glassy carbon electrode. Platinum $(\mathrm{Pt})$ gauze 52 mesh (Alfa Aesar) and $\mathrm{Ag} / \mathrm{AgCl}$ (BASi) were used as counter and reference electrodes, respectively. The cathode and anode parts of the cell were separated through an anion exchange membrane (Sustainion X37-50 Grade RT, Dioxide Materials). All experiments were performed in a $\mathrm{CO}_{2}$ saturated $\mathrm{KOH}: \mathrm{CC}(3 \mathrm{M}: 2 \mathrm{M})$ electrolyte with a $\mathrm{pH}$ of $14.5 \pm 0.1$. A two-compartment zero-gap solid polymer electrolyte flow electrolyzer was used to study the electrochemical performance where the working and counter electrodes are separated using an anion exchange membrane. Working electrodes (cathode) were prepared by brush-coating the solution of studied catalysts ( $\mathrm{W}_{2} \mathrm{C} \mathrm{NFs}$, Au NPs, and Cu NPs) on the gas diffusion layer (GDL, Sigracet 39 BC, Fuel Cell Store) electrodes with a geometrical surface area of $5 \mathrm{~cm}^{2}$. The counter electrode (anode) was prepared using a similar procedure where $\mathrm{IrO}_{2}$ powder (Sigma Aldrich) was used as the catalyst solution. The actual loadings of $0.1 \pm 0.01 \mathrm{mg} / \mathrm{cm}^{2}$ were determined by weighing the dry GDLs before catalyst deposition and coated GDLs after being dried in a vacuum oven overnight. As a separator in our experiments, we used an anion exchange membrane (Sustainion X37-50 Grade RT, Dioxide Materials) which was treated in $1 \mathrm{M}$ $\mathrm{KOH}$ overnight at $75^{\circ} \mathrm{C}$ and then washed with deionized water prior to use. Anolyte flow of KOH:CC (3 M:2 M) with a flow rate of $20 \mathrm{ml} / \mathrm{min}$ was fed to the anode compartment using a peristaltic pump (Masterflex, Cole-Parmer). A mass flow controller (SmartTrak 50, Sierra, calibrated with $\mathrm{CO}_{2}$ gas) connected to the $\mathrm{CO}_{2}$ humidifier kit, was used to feed the cathode compartment with a flow rate of $50 \mathrm{ml} / \mathrm{min}$.

PV cell characterization. A solar-powered flow cell was assembled by connecting the solid polymer electrolyte flow electrolyzer to a triple junction photovoltaic (TJPV) solar cell. The TJ-PV cell was characterized at different sun illuminations using a custom-made sun simulator light source and an InGaAs photodiode (Thorlabs, FDG03-CAL) with a known responsivity calibration curve. Our results indicated a maximum efficiency of $34.32 \%$ under one sun illumination used in our study.

Electrochemical characterization. Electrochemical experiments were performed using a Biologic Potentiostat SP-150. The CA technique was used to study the performance of TMC NFs i.e., $\mathrm{W}_{2} \mathrm{C}, \mathrm{Mo}_{2} \mathrm{C}, \mathrm{Nb}_{2} \mathrm{C}$, and $\mathrm{V}_{2} \mathrm{C}$ NFs and compared them with that of $\mathrm{Au}$ and $\mathrm{Cu}$ NPs. The $\mathrm{CA}$ experiments were carried out in the range of -0.45 to $-1.05 \mathrm{~V}$ vs RHE potentials. All experiments were performed under identical experimental conditions. The LSV technique was used to study the fundamentals of the cathodic half-cell reaction in the three-electrode cell setup. LSV curves were obtained by sweeping the potential between +0.2 and $-1.05 \mathrm{~V}$ vs RHE with a scan rate of $20 \mathrm{mV} / \mathrm{s}$. The conversion of $\mathrm{Ag} / \mathrm{AgCl}$ reference electrode potential to the RHE scale was calculated using the Nernst equation considering the $\mathrm{pH}$ of the solution $(\mathrm{pH}=14.5)$.

Product characterization. A gas chromatography system (GC, SRI, 8610 C) equipped with a flame ionization detector (FID) and a thermal conductivity detector (TCD) was used to detect and quantify the electrochemical $\mathrm{CO}_{2} \mathrm{RR}$ products. Ultra-high purity helium $(\mathrm{He})$ and nitrogen $\left(\mathrm{N}_{2}\right)$ gases (UHP $99.99 \%$, Airgas) were used as the carrier gas to identify any possible type of product. the signal response of the FID and TCD to each gaseous product (e.g., $\mathrm{H}_{2}, \mathrm{CO}, \mathrm{CH}_{4}$ and $\mathrm{C}_{2} \mathrm{H}_{4}$ ) was calibrated by analyzing a series of standard gas mixtures with known compositions prior to the experiments. To study the products, $1 \mathrm{~mL}$ sample of the headspace of the cell was injected into the GC system using a lock-in syringe (Hamilton). Moreover, an in situ differential electrochemical mass spectrometer (DEMS, Hiden Analytical, HPR-40) was used to validate the obtained information from the GC system by continuously detecting all possible products, even at trace amounts (partial pressure of $1 \times 10^{-13}$ Torr), during the electrochemical $\mathrm{CO}_{2} \mathrm{RR}$ (CA experiment), resulting in more precise measurement. The signal responses of the DEMS instrument for different products $\left(\mathrm{H}_{2}, \mathrm{CO}, \mathrm{CH}_{4}, \mathrm{C}_{2} \mathrm{H}_{4}, \mathrm{CH}_{3} \mathrm{OH}\right.$, and $\mathrm{C}_{2} \mathrm{H}_{5} \mathrm{OH}$ ) were calibrated by feeding standard samples into the mass spectrometer. An electron energy of $70 \mathrm{eV}$ was used for ionization of all species, with an emission current of $500 \mu \mathrm{A}$. All mass-selected product cations were detected by a secondary electron multiplier with a detector voltage of $1200 \mathrm{~V}$ for maximizing the signal-tonoise ratio of the products.

X-ray diffraction (XRD). The XRD technique was used to identify the phase purity and crystallinity of all studied catalysts $\left(\mathrm{W}_{2} \mathrm{C}, \mathrm{Mo}_{2} \mathrm{C}, \mathrm{Nb}_{2} \mathrm{C}, \mathrm{V}_{2} \mathrm{C} \mathrm{NFs}, \mathrm{Au}\right.$ $\mathrm{NPs}$, and $\mathrm{Cu} \mathrm{NPs}$ ) using a Bruker D2 PHASER diffractometer in Bragg-Brentano geometry employing a Ni filtered $\mathrm{Cu} K a$ radiation $(1.5405 \AA)$. The XRD patterns were obtained using a LynxEye linear position-sensitive detector and a step width of $0.2^{\circ} 2 \theta$ with a counting time of 1 s/step.

X-ray photoelectron spectroscopy (XPS). A Thermo-Scientific ESCALAB 250X instrument equipped with an electron flood and scanning ion gun was used to identify the oxidation states of the $\mathrm{W}_{2} \mathrm{C}$ NFs. All obtained spectra were analyzed using Thermo-Avantage software, considering the standard carbon peak at $284.8 \mathrm{eV}$ and relative sensitivity factors.

Ultraviolet photoelectron spectroscopy (UPS). Surface work function measurements were carried out using the UPS technique. All UPS data were acquired by a Thermo-Scientific ESCALAB 250Xi instrument using He I $(21.2 \mathrm{eV})$ ultraviolet radiation and a pass energy of $8.95 \mathrm{eV}$.

Scanning transmission electron microscopy (STEM). $\mathrm{W}_{2} \mathrm{C}$ NFs were characterized at the atomic scale using a spherical aberration-corrected JEOL JEMARM 200CF STEM with a cold field emission gun operating at $200 \mathrm{kV}$. HAADF detector with $22 \mathrm{mrd}$ inner-detector angle and $\mathrm{BF}$ detector were utilized to obtain the atomic resolution images.

Theoretical study. We performed a comparative DFT analysis for the observed catalytic activity and reactivity of $\mathrm{W}_{2} \mathrm{C}$ NFs with $\mathrm{Au}$ and other TMCs using the SIESTA package, with Perdew-Burke-Ernzerhof functional with a double-zeta with polarization (DZP) localized basis set and the norm-conserving TroullierMartins pseudopotentials. Calculations of DOS for bulk and slab geometries of $\mathrm{Au}$ and TMCs were performed using the Effective Screening Method (ESM) ${ }^{73}$ for Brillouin zones of the unit cells sampled by Monkhorst-Pack k-point grids of size $9 \times 9 \times 9$ and $1 \times 9 \times 9$, respectively, together with a plane-wave cutoff of $300.0 \mathrm{Ry}$. The optimization of the atomic positions and cell parameters were carried out using a conjugate-gradient algorithm until a maximum atomic force tolerance of $0.04 \mathrm{eV} / \AA ̊$ and a maximum stress component along each periodic direction of lower than $1 \mathrm{GPa}$ were achieved. The Vienna ab initio Simulation Package (VASP, version 5.4.4) with PAW (projector augmented wave method) and

Perdew-Burke-Ernzerhof exchange-correlation functionals were used to analyze the adsorption free energies of various molecular species on the (101) surface of $\mathrm{M}_{2} \mathrm{C}(\mathrm{M}=\mathrm{W}, \mathrm{V}, \mathrm{Mo}, \mathrm{Nb})$. All the VASP calculations were performed for neutral non-spin-polarized systems and a dipolar electrostatic correction was used along the normal to the surface of the slab. Next, we used the tetrahedron method with Blöchl corrections and $1 \times 3 \times 3$ Monkhorst-Pack grid k-point sampling for the calculations of total electronic energy (smearing $\sigma=0.1$ ). The adsorption free energies were then used within the CHE model ${ }^{64-66}$ to evaluate the lowest free energy pathways and the limiting reaction potentials. 


\section{Data availability}

The data supporting the findings of this study are available within the article and its Supplementary Information. Other relevant data are available from the corresponding author upon reasonable request. The Source data underlying figures of this manuscript are provided as a Source Data file which is provided with this paper. The X-ray crystallographic coordinates for structures reported in this study have been deposited at the Cambridge Crystallographic Data Centre (CCDC), under deposition numbers 2089992-2089995. Source data are provided with this paper.

Received: 12 March 2021; Accepted: 6 July 2021;

Published online: 20 August 2021

\section{References}

1. Ross, M. B. et al. Designing materials for electrochemical carbon dioxide recycling. Nat. Catal. 2, 648-658 (2019).

2. Lewis, N. S. Toward cost-effective solar energy use. Science 315, 798-801 (2007).

3. Chen, Y., Lewis, N. S. \& Xiang, C. Operational constraints and strategies for systems to effect the sustainable, solar-driven reduction of atmospheric $\mathrm{CO}_{2}$. Energy Environ. Sci. 8, 3663-3674 (2015)

4. Esmaeili Rad, F., Abbasian, J. \& Arastoopour, H. Numerical simulation of $\mathrm{CO}_{2}$ adsorption in a fluidized bed using solid-supported amine sorbent. Can. J. Chem. Eng. 99, 1595-1606 (2020).

5. Shih, C. F., Zhang, T., Li, J. \& Bai, C. Powering the future with liquid sunshine. Joule 2, 1925-1949 (2018).

6. Birdja, Y. Y. et al. Advances and challenges in understanding the electrocatalytic conversion of carbon dioxide to fuels. Nat. Energy 4, 732-745 (2019).

7. Rosen, B. A. et al. Ionic liquid-mediated selective conversion of $\mathrm{CO}_{2}$ to $\mathrm{CO}$ at low overpotentials. Science 334, 643-644 (2011).

8. Asadi, M. et al. Nanostructured transition metal dichalcogenide electrocatalysts for $\mathrm{CO}_{2}$ reduction in ionic liquid. Science 353, 467-470 (2016).

9. Rosen, B. A., Zhu, W., Kaul, G., Salehi-Khojin, A. \& Masel, R. I. Water enhancement of $\mathrm{CO} 2$ conversion on silver in 1-ethyl-3-methylimidazolium tetrafluoroborate. J. Electrochem. Soc. 160, H138-H141 (2012).

10. Abbasi, P. et al. Tailoring the edge structure of molybdenum disulfide toward electrocatalytic reduction of carbon dioxide. ACS Nano 11, 453-460 (2017).

11. Asadi, M. et al. Robust carbon dioxide reduction on molybdenum disulphide edges. Nat. Commun. 5, 4470 (2014).

12. Chan, K., Tsai, C., Hansen, H. A. \& Nørskov, J. K. Molybdenum sulfides and selenides as possible electrocatalysts for $\mathrm{CO}_{2}$ reduction. ChemCatChem 6 1899-1905 (2014).

13. Hong, X., Chan, K., Tsai, C. \& Nørskov, J. K. How doped $\mathrm{MoS}_{2}$ breaks transition-metal scaling relations for $\mathrm{CO}_{2}$ electrochemical reduction. ACS Catal. 6, 4428-4437 (2016)

14. Clark, E. L. et al. Influence of atomic surface structure on the activity of Ag for the electrochemical reduction of $\mathrm{CO}_{2}$ to CO. ACS Catal. 9, 4006-4014 (2019).

15. Rosen, J. et al. Mechanistic insights into the electrochemical reduction of $\mathrm{CO}_{2}$ to CO on nanostructured Ag surfaces. ACS Catal. 5, 4293-4299 (2015).

16. Fang, Y. \& Flake, J. C. Electrochemical reduction of $\mathrm{CO}_{2}$ at functionalized $\mathrm{Au}$ electrodes. J. Am. Chem. Soc. 139, 3399-3405 (2017).

17. Zhao, Y., Wang, C., Liu, Y., MacFarlane, D. R. \& Wallace, G. G. Engineering surface amine modifiers of ultrasmall gold nanoparticles supported on reduced graphene oxide for improved electrochemical $\mathrm{CO}_{2}$ reduction. $A d v$. Energy Mater. 8, 1801400 (2018).

18. Lee, H. E. et al. Concave rhombic dodecahedral Au nanocatalyst with multiple high-index facets for $\mathrm{CO}_{2}$ reduction. ACS Nano 9, 8384-8393 (2015)

19. Zhao, S., Jin, R. \& Jin, R. Opportunities and challenges in $\mathrm{CO}_{2}$ reduction by gold- and silver-based electrocatalysts: from bulk metals to nanoparticles and atomically precise nanoclusters. ACS Energy Lett. 3, 452-462 (2018).

20. Zhang, Z. et al. Rational design of bi nanoparticles for efficient electrochemical $\mathrm{CO}_{2}$ reduction: the elucidation of size and surface condition effects. ACS Catal. 6, 6255-6264 (2016).

21. Todoroki, N. et al. Surface atomic arrangement dependence of electrochemical $\mathrm{CO}_{2}$ reduction on gold: online electrochemical mass spectrometric study on low-index Au(hkl) surfaces. ACS Catal. 9, 1383-1388 (2019).

22. Back, S., Yeom, M. S. \& Jung, Y. Active sites of Au and Ag nanoparticle catalysts for $\mathrm{CO}_{2}$ electroreduction to CO. ACS Catal. 5, 5089-5096 (2015).

23. Kim, K. S., Kim, W. J., Lim, H. K., Lee, E. K. \& Kim, H. Tuned chemical bonding ability of $\mathrm{Au}$ at grain boundaries for enhanced electrochemical $\mathrm{CO}_{2}$ reduction. ACS Catal. 6, 4443-4448 (2016).

24. Tao, Z., Wu, Z., Yuan, X., Wu, Y. \& Wang, H. Copper-gold interactions enhancing formate production from electrochemical $\mathrm{CO}_{2}$ reduction. ACS Catal. 9, 10894-10898 (2019).
25. Morales-Guio, C. G. et al. Improved $\mathrm{CO}_{2}$ reduction activity towards $\mathrm{C} 2+$ alcohols on a tandem gold on copper electrocatalyst. Nat. Catal. 1, 764-771 (2018).

26. Liu, M. et al. Enhanced electrocatalytic $\mathrm{CO}_{2}$ reduction via field-induced reagent concentration. Nature 537, 382 (2016).

27. Asadi, M. et al. Highly efficient solar-driven carbon dioxide reduction on molybdenum disulfide catalyst using choline chloride-based electrolyte. Adv Energy Mater. 9, 1803536 (2019).

28. Nitopi, S. et al. Progress and perspectives of electrochemical $\mathrm{CO}_{2}$ reduction on copper in aqueous electrolyte. Chem. Rev. 119, 7610-7672 (2019).

29. Dinh, C. T. et al. $\mathrm{CO}_{2}$ electroreduction to ethylene via hydroxide-mediated copper catalysis at an abrupt interface. Science 360, 783-787 (2018).

30. Li, F. et al. Molecular tuning of $\mathrm{CO}_{2}$-to-ethylene conversion. Nature 577, 509-513 (2020).

31. Wakerley, D. et al. Bio-inspired hydrophobicity promotes $\mathrm{CO}_{2}$ reduction on a Cu surface. Nat. Mater. 18, 1222-1227 (2019).

32. Jiang, $\mathrm{K}$. et al. Metal ion cycling of $\mathrm{Cu}$ foil for selective $\mathrm{C}-\mathrm{C}$ coupling in electrochemical $\mathrm{CO}_{2}$ reduction. Nat. Catal. 1, 111-119 (2018).

33. Zhang, X., Sun, X., Guo, S. X., Bond, A. M. \& Zhang, J. Formation of lattice dislocated bismuth nanowires on copper foam for enhanced electrocatalytic $\mathrm{CO}_{2}$ reduction at low overpotential. Energy Environ. Sci. 12, 1334-1340 (2019).

34. Iijima, G., Inomata, T., Yamaguchi, H., Ito, M. \& Masuda, H. Role of a hydroxide layer on $\mathrm{Cu}$ electrodes in electrochemical $\mathrm{CO}_{2}$ reduction. ACS Catal. 9, 6305-6319 (2019).

35. Liang, Z. et al. Copper-on-nitride enhances the stable electrosynthesis of multi-carbon products from $\mathrm{CO}_{2}$. Nat. Commun. 9, 3828 (2018)

36. Garza, A. J., Bell, A. T. \& Head-Gordon, M. Mechanism of $\mathrm{CO}_{2}$ reduction at copper surfaces: pathways to $\mathrm{C}_{2}$ products. ACS Catal. 8, 1490-1499 (2018).

37. Ringe, $\mathrm{S}$. et al. Understanding cation effects in electrochemical $\mathrm{CO}_{2}$ reduction. Energy Environ. Sci. 12, 3001-3014 (2019).

38. $\mathrm{Li}, \mathrm{C} . \mathrm{W}$. \& Kanan, M. W. $\mathrm{CO}_{2}$ reduction at low overpotential on $\mathrm{Cu}$ electrodes resulting from the reduction of thick $\mathrm{Cu}_{2} \mathrm{O}$ films. J. Am. Chem. Soc 134, 7231-7234 (2012).

39. Gogotsi, Y. \& Anasori, B. The rise of MXenes. ACS Nano 13, 8491-8494 (2019).

40. Anasori, B. et al. Two-dimensional, ordered, double transition metals carbides (MXenes). ACS Nano 9, 9507-9516 (2015).

41. Hantanasirisakul, K. \& Gogotsi, Y. Electronic and optical properties of 2D transition metal carbides and nitrides (MXenes). Adv. Mater. 30, 1804779 (2018).

42. Esmaeilirad, M., Kondori, A., Ruiz Belmonte, A. \& Asadi, M. Electroreduction of carbon dioxide to methane enabled by molybdenum carbide nanocatalyst. ECS Meet. Abstr. MA2020-02, 3234 (2020).

43. Lei, J., Kutana, A. \& Yakobson, B. I. Predicting stable phase monolayer $\mathrm{Mo}_{2} \mathrm{C}$ (MXene), a superconductor with chemically-tunable critical temperature. $J$. Mater. Chem. C. 5, 3438-3444 (2017).

44. Lewandowski, M., Szyma, A., Sayag, C. \& Beaunier, P. Applied catalysis B: environmental atomic level characterization and sulfur resistance of unsupported $\mathrm{W}_{2} \mathrm{C}$ during dibenzothiophene hydrodesulfurization. Classical kinetic simulation of the reaction. Appl. Catal. B Environ. 144, 750-759 (2014).

45. Kondori, A. et al. Identifying catalytic active sites of trimolybdenum phosphide $\left(\mathrm{Mo}_{3} \mathrm{P}\right)$ for electrochemical hydrogen evolution. Adv. Energy Mater. 9, 1900516 (2019).

46. Esmaeilirad, M. et al. Oxygen functionalized copper nanoparticles for solardriven conversion of carbon dioxide to methane. ACS Nano 14, 2099-2108 (2020).

47. Vasilyev, D. V. \& Dyson, P. J. The role of organic promoters in the electroreduction of carbon dioxide. ACS Catal. 11, 1392-1405 (2021)

48. Zhang, T. et al. Highly dispersed, single-site copper catalysts for the electroreduction of $\mathrm{CO}_{2}$ to methane. J. Electroanal. Chem. 875113862 (2020).

49. $\mathrm{Wu}$, J. et al. A metal-free electrocatalyst for carbon dioxide reduction to multicarbon hydrocarbons and oxygenates. Nat. Commun. 7, 13869 (2016).

50. De Gregorio, G. L. et al. Facet-dependent selectivity of $\mathrm{Cu}$ catalysts in electrochemical $\mathrm{CO}_{2}$ reduction at commercially viable current densities. ACS Catal. 10, 4854-4862 (2020).

51. Chen, S. et al. Highly selective carbon dioxide electroreduction on structureevolved copper perovskite oxide toward methane production. ACS Catal. 10, 4640-4646 (2020)

52. Wang, X. et al. Efficient methane electrosynthesis enabled by tuning local CO2 availability. J. Am. Chem. Soc. 142, 3525-3531 (2020).

53. Weng, Z. et al. Active sites of copper-complex catalytic materials for electrochemical carbon dioxide reduction. Nat. Commun. 9, 415 (2018).

54. Manthiram, K., Beberwyck, B. J. \& Alivisatos, A. P. Enhanced electrochemical methanation of carbon dioxide with a dispersible nanoscale copper catalyst. $J$. Am. Chem. Soc. 136, 13319-13325 (2014). 
55. Jones, J. P., Prakash, G. K. S. \& Olah, G. A. Electrochemical $\mathrm{CO}_{2}$ reduction: recent advances and current trends. Isr. J. Chem. 54, 1451-1466 (2014).

56. Kuhl, K. P., Cave, E. R., Abram, D. N. \& Jaramillo, T. F. New insights into the electrochemical reduction of carbon dioxide on metallic copper surfaces. Energy Environ. Sci. 5, 7050-7059 (2012).

57. Hoang, T. T. H. et al. Nanoporous copper-silver alloys by additive-controlled electrodeposition for the selective electroreduction of $\mathrm{CO}_{2}$ to ethylene and ethanol. J. Am. Chem. Soc. 140, 5791-5797 (2018).

58. Kim, S. K., Zhang, Y. J., Bergstrom, H., Michalsky, R. \& Peterson, A. Understanding the low-overpotential production of $\mathrm{CH}_{4}$ from $\mathrm{CO}_{2}$ on $\mathrm{Mo}_{2} \mathrm{C}$ catalysts. ACS Catal. 6, 2003-2013 (2016).

59. Holzwarth, U. \& Gibson, N. The Scherrer equation versus the Debye-Scherrer equation. Nat. Nanotechnol. 6, 534 (2011).

60. Patterson, A. L. The Scherrer formula for X-ray particle size determination. Phys. Rev. 56, 978-982 (1939).

61. Esmaeilirad, M., Zabihi, M., Shayegan, J. \& Khorasheh, F. Oxidation of toluene in humid air by metal oxides supported on Г-alumina. J. Hazard. Mater. 333, 293-307 (2017).

62. Wang, Q. H., Kalantar-Zadeh, K., Kis, A., Coleman, J. N. \& Strano, M. S Electronics and optoelectronics of two-dimensional transition metal dichalcogenides. Nat. Nanotechnol. 7, 699-712 (2012).

63. Bienen, F., Kopljar, D., Geiger, S., Wagner, N. \& Friedrich, K. A. Investigation of $\mathrm{CO}_{2}$ electrolysis on tin foil by electrochemical impedance spectroscopy. ACS Sustain. Chem. Eng. 8, 5192-5199 (2020).

64. Nørskov, J. K. et al. Origin of the overpotential for oxygen reduction at a fuelcell cathode. J. Phys. Chem. B 108, 17886-17892 (2004).

65. Rossmeisl, J., Logadottir, A. \& Nørskov, J. K. Electrolysis of water on (oxidized) metal surfaces. Chem. Phys. 319, 178-184 (2005).

66. Peterson, A. A., Abild-Pedersen, F., Studt, F., Rossmeisl, J. \& Nørskov, J. K. How copper catalyzes the electroreduction of carbon dioxide into hydrocarbon fuels. Energy Environ. Sci. 3, 1311-1315 (2010).

67. $\mathrm{Li}, \mathrm{N}$. et al. Understanding of electrochemical mechanisms for $\mathrm{CO}_{2}$ capture and conversion into hydrocarbon fuels in transition-metal carbides (MXenes). ACS Nano 11, 10825-10833 (2017).

68. Garza, A. J., Bell, A. T. \& Head-Gordon, M. Is subsurface oxygen necessary for the electrochemical reduction of $\mathrm{CO}_{2}$ on copper? J. Phys. Chem. Lett. 9, 601-606 (2018).

69. Favaro, M. et al. Subsurface oxide plays a critical role in $\mathrm{CO}_{2}$ activation by $\mathrm{Cu}(111)$ surfaces to form chemisorbed $\mathrm{CO}_{2}$, the first step in reduction of $\mathrm{CO}_{2}$. Proc. Natl Acad. Sci. USA 114, 6706-6711 (2017).

70. Lim, D. H. et al. Carbon dioxide conversion into hydrocarbon fuels on defective graphene-supported $\mathrm{Cu}$ nanoparticles from first principles. Nanoscale 6, 5087-5092 (2014).

71. Kondori, A. et al. Kinetically stable oxide overlayers on $\mathrm{Mo}_{3} \mathrm{P}$ nanoparticles enabling lithium-air batteries with low overpotentials and long cycle life. Adv. Mater. 32, 2004028 (2020).

72. García de Arquer, F. P. et al. $\mathrm{CO}_{2}$ electrolysis to multicarabon products at activities greater than $1 \mathrm{~A} \mathrm{~cm}^{-2}$. Science 367, $661 \mathrm{LP}-661666$ (2020).

73. Otani, M. \& Sugino, O. First-principles calculations of charged surfaces and interfaces: A plane-wave nonrepeated slab approach. Phys. Rev. B 73, 115407 (2006).

\section{Acknowledgements}

Mohammad Asadi's work was supported by Illinois Institute of Technology start-up funding, Wanger Institute for Sustainable Energy Research (WISER) Institute for Sustainable Energy Research (WISER) seed fund (262029 221E 2300), American Institute of Architects (AIA) Upjohn Development Research Grant (387523 240 M 2301) and the Soft and Hybrid Nanotechnology Experimental (SHyNE) Resource (NSF ECCS-152205) funding at Northwestern University. This work was also supported by the Molecular Foundry and its compute cluster (vulcan), managed by the High-Performance
Computing Services Group, at Lawrence Berkeley National Laboratory (LBNL), and by the National Energy Research Scientific Computing Center (NERSC) at LBNL. LBML resources are provided by the Office of Science of the US Department of Energy under contract No. DE-AC02-05CH11231. Reza Shahbazian-Yassar efforts were supported by NSF (DMR-1809439). We acknowledge the EPIC facility (NUANCE Center, Northwestern University), which has received support from the MRSEC program (NSF DMR 1121262) at the Materials Research Center; the Nanoscale Science and Engineering Center (NSF EEC-0647560) at the International Institute for Nanotechnology; and the State of Illinois, through the International Institute for Nanotechnology. The authors acknowledge Dr. Rao Tatavarti from Micro-Link Device, Inc. at Chicago for providing the triple junction PV cell. This work made use of instruments in the Electron Microscopy Service (Research Resources Center, UIC). The acquisition of the UIC JEOL JEMARM200CF was supported by an MRI-R2 grant from the National Science Foundation (Award No. DMR-0959470).

\section{Author contributions}

M.A. and M.E. conceived the idea of the work. M.E. synthesized the nanostructured materials and designed and fabricated the experimental devices. M.E., A.K., A.R.B., P.N.M.D., and J.P. performed electrocatalysis experiments and data analysis. R.A. contributed to flow cell design. D.P., A.B., A.S.M., and J.Q. carried out DFT calculations and CHE model analysis. M.E., K.K., and C.U.S. did the XRD characterization and analysis. M.E. and A.K. did the XPS, UPS, DLS, and NMR characterizations. B.S., M.T.S., and R.S.Y. performed the STEM characterization. M.A. supervised M.E., A.K., A.R.B., P.N.M.D., and J.P. efforts. All authors discussed the results and assisted with manuscript preparation.

\section{Competing interests}

M.A., M.E., A.K., and A.R.B. filed a patent application. The remaining authors declare no competing interests.

\section{Additional information}

Supplementary information The online version contains supplementary material available at https://doi.org/10.1038/s41467-021-25295-y.

Correspondence and requests for materials should be addressed to D.P. or M.A.

Peer review information Nature Communications thanks David Willock and the other anonymous reviewers for their contribution to the peer review of this work.

Reprints and permission information is available at http://www.nature.com/reprints

Publisher's note Springer Nature remains neutral with regard to jurisdictional claims in published maps and institutional affiliations.

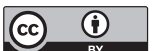

Open Access This article is licensed under a Creative Commons Attribution 4.0 International License, which permits use, sharing, adaptation, distribution and reproduction in any medium or format, as long as you give appropriate credit to the original author(s) and the source, provide a link to the Creative Commons license, and indicate if changes were made. The images or other third party material in this article are included in the article's Creative Commons license, unless indicated otherwise in a credit line to the material. If material is not included in the article's Creative Commons license and your intended use is not permitted by statutory regulation or exceeds the permitted use, you will need to obtain permission directly from the copyright holder. To view a copy of this license, visit http://creativecommons.org/ licenses/by/4.0/.

(C) The Author(s) 2021 